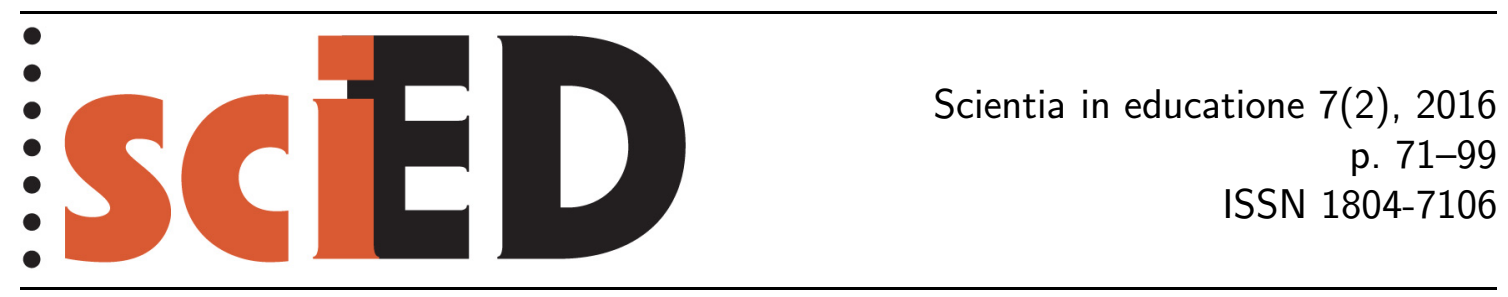

\title{
Didaktické znalosti obsahu budoucích učitelů 1. stupně základní školy před studiem didaktiky matematiky
}

\author{
Libuše Samková
}

\begin{abstract}
Abstrakt
Předkládaná studie se věnuje problematice zkoumání didaktických znalostí obsahu v matematice v kontextu vzdělávání budoucích učitelů 1. stupně ZŠ. Jako nástroj pro zkoumání těchto znalostí představuje výukovou pomůcku Concept Cartoons. První část příspěvku uvádí přehled souvisejícího výzkumu, v druhé části popisujeme kvalitativní výzkum s přípravnou studií. Přípravná studie byla zaměřena na způsob použití Concept Cartoons jako nástroje pro zkoumání didaktických znalostí obsahu, vlastní výzkum byl zaměřen na zkoumání didaktických znalostí obsahu u budoucích učitelů 1. stupně ZŠ. Účastníky výzkumu byli studenti druhého ročníku pětiletého magisterského oboru Učitelství pro 1. stupeň ZŠ, kteří ještě nenavštěvovali univerzitní kurz didaktiky matematiky. Zájem byl soustředěn na znalosti v oblasti číselných oborů. Výsledky šetření potvrdily, že neformální základy didaktických znalostí obsahu mohou někteři budoucí učitelé úspěšně získávat z vlastních zkušeností v roli žáka/studenta na základní škole, střední škole a během nedidaktických univerzitních kurzů. Analýza dat odhalila několik respondentů s dobrou znalostí učebních úloh a žákových miskoncepcí. Zároveň jsme však objevili i respondenty, kteří nejsou schopni rozlišovat mezi identifikací, přičinou a nápravou chyby a kteří mají o možném uvažování žáků nerealistické mylné představy. Obecné výsledky šetření jsou ve studii doloženy konkrétními datovými úryvky.
\end{abstract}

Klíčová slova: didaktické znalosti obsahu, budoucí učitelé 1 . stupně ZS̆, matematické vzdělávání, Concept Cartoons.

\section{Pedagogical Content Knowledge in Mathematics of Future Elementary School Teachers Who Are About to Start Their Mathematics Education Courses}

\begin{abstract}
The study focuses on investigating pedagogical content knowledge in mathematics in the context of future elementary school teachers' education. The primary strategy explored in this study is the use of a teaching tool called "concept cartoons". The first part of the
\end{abstract}


contribution gives an overview of the relevant research, while the second part describes our own empirical research and a preparatory study. The preparatory study focused on the ways in which concept cartoons could be used as a tool for investigating pedagogical content knowledge. The research itself focused on the investigation of pedagogical content knowledge of future primary elementary school teachers. The participants of our research were students of the second year of a five-year master degree university programme for future elementary school teachers who had not yet attended the respective mathematics education college course. We focused on assessing their knowledge in the field of number systems. The results of the research have confirmed that some future teachers are able to acquire some expertise in pedagogical content knowledge in non-formal settings, during their attendance of K-12or non-didactic university courses. The data analysis revealed the several participants had good knowledge of the relevant tasks and pupils' misconceptions. Some participants, however, were unable to distinguish between the act of identifying a mistake and the ability to identify the cause and potential remedy of a mistake. They also had unrealistic expectations about pupils' levels of reasoning. General results of the research are demonstrated by sample data segments.

Key words: pedagogical content knowledge, future primary school teachers, mathematics education, Concept Cartoons.

\section{ÚVOD}

Na základě celoživotních zkušeností a studia literatury jsem přesvědčen, že nejdůležitější forma kultivace didaktických znalostí obsahu učitele matematiky se rodí a pěstuje v samém průběhu učitelského vzdělávání, v němž od samého začátku jsou spjaty odborně matematická a didaktická složka, přičemž jejich sjednocení je zabezpečeno důrazem na proces utváření matematických pojmů a postupů, při soustavné péči o porozumění pojmům, pěstování př́islušných činností a komunikaci. (Kuřina, 2012: s. 172)

Jednou z důležitých součástí učitelovy profese jsou jeho vlastní didaktické znalosti obsahu. Tyto znalosti získává učitel celý život: již od první třídy základní školy během studia předmětu, který bude později učit (a i při studiu jiných předmětů), na vysoké škole hlavně během studia didaktiky tohoto předmětu a během pedagogických praxí, a pak po celý profesní život při vlastní výuce a při diskusích s kolegy. A tak se nabízí otázka, na jaké úrovni jsou didaktické znalosti obsahu v různých stádiích učitelova života.

V tomto článku se věnujeme problematice didaktických znalostí obsahu v matematice v kontextu vzdělávání budoucích učitelů 1. stupně základní školy. Jako nástroj pro zkoumání didaktických znalostí obsahu představujeme výukovou pomůcku zvanou Concept Cartoons.

V první části př́ispěvku uvádíme přehled souvisejícího výzkumu, včetně dosavadního využití Concept Cartoons v př́rodovědném a v matematickém vzdělávání. V druhé části popisujeme empirický kvalitativní výzkum s př́pravnou studií: přípravná studie byla zaměřena na zpo̊sob použití Concept Cartoons jako nástroje pro zkoumání didaktických znalostí obsahu, vlastní výzkum byl zaměřen na zkoumání těchto znalostí u budoucích učitelů 1 . stupně ZS̆, kteří ještě nenavštěvovali univerzitní kurz didaktiky matematiky. Zájem byl soustředěn na znalosti v oblasti číselných oborů v rozsahu učiva odpovídajícímu 1. stupni ZŠS. 


\section{UČITELOVY ZNALOSTI}

Učitelé a jejich znalosti ovlivňující průběh vyučování jsou středem zájmu mnoha výzkumů, v tomto př́spěvku se budeme věnovat oblastem vztahujícím se $\mathrm{k}$ Shulmanově konceptu poznatkové báze učitelství a k Rowlandově konceptu znalostního kvarteta.

\subsection{Poznatková BÁze uČItelství}

Shulmanově přístupu a jeho terminologickému vymezení v českém prostředí se jako první podrobněji věnoval Janík (2004), z jeho publikace také přebíráme českou terminologii. Shulmanova teorie je založena na tzv. poznatkové bázi učitelství tvořené sedmi kategoriemi, z nichž tři jsou vázány na obsah vzdělávání (1986):

- znalosti vědních a jiných obsahů (znalosti obsahu);

- didaktické znalosti obsahu;

- znalosti kurikula;

a čtyři jsou obecné povahy (1987):

- obecné pedagogické znalosti;

- znalosti o žákovi a jeho charakteristikách;

- znalosti o kontextech vzdělávání;

- znalosti o cílech, smyslu a hodnotách vzdělávání.

My se zaměříme na znalosti obsahu ${ }^{1}$ a na didaktické znalosti obsahu ${ }^{2}$. Znalosti obsahu budeme chápat jako znalosti „pro sebe“, tedy vlastní znalosti, které jedinec uplatní při svém studiu odborného předmětu (napřr. při řešení odborného problému, při čtení odborného textu, při učení se apod.). Didaktické znalosti obsahu budeme chápat jako znalosti „pro pomoc jiným“, tedy znalosti, které jedinec uplatní, pokud učí někoho jiného. Vztah mezi těmito dvěma kategoriemi znalostí může být u různých jedinců různý, obecně lze znalosti obsahu a didaktické znalosti obsahu považovat za dvě nestejné množiny s neprázdným průnikem.

Podle Grossmanové (1990, cit. dle Janík et al., 2007: s. 31) sestávají didaktické znalosti obsahu ze čtyř komponent:

- znalosti a pojetí cílů, k nimž má směřovat vyučování v daném předmětu na určitém stupni školy;

- znalosti kurikulárních materiálio, které jsou pro vyučování v daném předmětu k dispozici, znalosti horizontálních a vertikálních vazeb mezi předměty v kurikulu;

- znalosti žákových koncepcí a miskoncepcí určitého učiva v rámci vyučovacího předmětu, znalosti vztahující se k možnostem a mezím žákova porozumění;

- znalosti výukových strategií a reprezentací pro vyučování určitého učiva.

Náš příspěvek se vztahuje hlavně k posledním dvěma komponentám.

Více podrobností o didaktických znalostech obsahu lze nalézt $\mathrm{v}$ publikaci (Janík et al., 2007); vymezení didaktických znalostí obsahu v českém (resp. česko-německém) vzdělávacím prostředí se věnoval i Kuřina $(2011,2012)$.

\footnotetext{
${ }^{1} \mathrm{~V}$ angličtině subject matter content knowledge, zkr. SMK.

${ }^{2} \mathrm{~V}$ angličtině pedagogical content knowledge, zkr. PCK.
} 


\subsection{ZnAlostní KVARTETO}

V kontextu vyučování matematice na prvním stupni základní školy se výzkumu učitelových znalostí vázaných na obsah také věnovali Rowland a jeho spolupracovníci. Jako součást studie podrobně popsané v publikacích (Rowland, Huckstep \& Thwaites, 2005; Rowland, Turner, Thwaites \& Huckstep, 2009; Rowland, Turner \& Thwaites, 2014) pořizovali videozáznamy hodin matematiky během souvislých praxí studentů závěrečných ročníků studia učitelství pro 1. stupeň. Při kvalitativní analýze videozáznamů v designu zakotvené teorie ${ }^{3}$ identifikovali celkem 20 kategorií učitelových znalostí, které mají významný vliv na dění ve třídě, a posléze tyto kategorie roztřídili do čtyř skupin, tzv. dimenzí:

- základní znalosti (teoretická průprava učitele a jeho přesvědčení);

- znalosti reprezentací (způsob předvedení učiva, využití pomůcek, analogie, příklady, názorné ukázky);

- znalosti souvislostí (návaznost učiva v rámci hodiny i mezi hodinami, správné řazení úloh a př́ikladi̊);

- znalosti v nepředvídaných situacích (reakce na nečekané či neplánované události).

Takto vytvořené schéma nazvali znalostní kvarteto ${ }^{4}$.

Rowland et al. (2009) zmiňují i Shulmanovu poznatkovou bázi učitelství a přibližně vymezují vztah dimenzí znalostního kvarteta a (didaktických) znalostí obsahu:

- základní znalosti zahrnují většinu znalostí obsahu;

- znalosti reprezentací jsou většinou didaktickými znalostmi obsahu;

- znalosti souvislostí - učitelovy vlastní jsou podmnožinou znalostí obsahu, určené pro žáky jsou podmnožinou didaktických znalostí obsahu;

- znalosti v nepředvídaných situacích zahrnují kombinaci obou kategorií.

V tomto příspěvku se mj. budeme podrobněji věnovat čtvrté dimenzi znalostního kvarteta a její kategorii „reakce učitele na podněty žáků․ Tato kategorie se týká schopnosti učitele reagovat přesvědčivě, uvážlivě a zasvěceně na ústní či písemné nápady, návrhy a názory žáků.

Rámec znalostního kvarteta byl úspěšně využit jako základní platforma pro analýzu několika videozáznamů z výuky na 2 . stupni ZŠ a jeho autoři plánují rozššririt a př́padně modifikovat systém kategorií tak, aby odpovídal výuce na 1 . i 2 . stupni ZŠ (Rowland, Thwaites \& Jared, 2016).

\subsection{ZKOUMÁNí DIDAKTICKÝCH ZNALOSTÍ OBSAHU}

Vzhledem k rozmanitosti struktury didaktických znalostí obsahu je rozmanitý i repertoár přístupů, metod a technik uplatňovaných při jejich zkoumání. Výzkumná data jsou získávána prostřednictvím rozhovorů s učiteli o jejich výuce, pozorováním výuky, pozorováním diskuse několika učitelů nad tím, jak vyučovat určitému učivu, z pojmových map nebo komentovaných souhrnů učiva vytvořených učiteli, z učitelových vyjádření ke zpracování učiva $\mathrm{v}$ učebnici nebo ke kritickým situacím z výuky apod. (podrobný přehled výzkumných studií a používaných metod nabízí Janík, 2009; Depaepe, Verschaffel \& Kelchtermans, 2013).

\footnotetext{
${ }^{3}$ Více o zakotvené teorii naleznete např. v knize od Švaříčka a Śed’ové (2014).

${ }^{4} \mathrm{~V}$ angličtině knowledge quartet; anglické názvy dimenzí: foundation, transformation, connection, contingency; vlastní překlad.
} 
Z pohledu didaktických znalostí matematického obsahu si pozornost zaslouží sada studií provedených v rámci výzkumného projektu COACTIV (souhrn projektu nabízí např. Krauss, Baumert \& Blum, 2008). V rámci projektu byly vytvořeny testy pro zjištování znalostí obsahu a didaktických znalostí obsahu u učitelů matematiky na 2. stupni ZŠ. Tyto testy byly předloženy učitelům, jejichž žáci se zúčastnili testování PISA. Bylo tak možné zkoumat vztahy mezi znalostmi učitelů a znalostmi jejich žáků.

Na projekt COACTIV navázalo mnoho dalších studií, jedna z nich se např́klad zabývala vlivem učitelova vzdělání na jeho znalosti obsahu a didaktické znalosti obsahu (Kleickmann et al., 2013). Tato studie poukazuje na to, že (didaktické) znalosti obsahu mohou učitelé získávat ze tří hlavních zdrojů:

- z vlastních zkušeností v roli žáka;

- v rámci univerzitní přípravy a kurzů dalšího vzdělávání učitelů;

- z vlastních zkušeností v roli učitele.

Dále upozornila na to, že vlastní zkušenosti v roli žáka pomáhají vytvořit neformální základy didaktických znalostí obsahu (např. pozorováním vlastních učitelů a spolužáků). Pro lepší zmapování vlivu vzdělání na (didaktické) znalosti obsahu tato studie porovnává znalosti budoucích učitelů matematiky v různých fázích univerzitní přípravy se znalostmi zkušených učiteli̊. U didaktických znalostí obsahu se zaměřuje na tři komponenty:

(i) znalosti učebních úloh (různých způsobů jejich řešení);

(ii) znalosti žákových poznávacích procesů (strategií, miskoncepcí, možných obtíží, zdrojů možného neporozumění apod.);

(iii) znalosti vyučování (různých reprezentací, modelů, vysvětlení).

Test byl sestaven z otevřených otázek, které mohou mít více správných odpovědí. Odpovědi na testové otázky byly bodovány. Př́klady testových otázek pro jednotlivé komponenty:

(i) Jak se změní obsah čtverce, pokud jeho stranu ztrojnásobíme? Svou odpověd' zdůvodněte. Uved'te co nejvíce různých způsobů řešení této úlohy (a co nejvíce různých zdůvodnění).

(ii) Obsah rovnoběžníku můžeme vypočítat jako součin jeho základny a výšky. Načrtněte takový rovnoběžník, u kterého by žáci mohli mít s tímto zpo̊sobem výpočtu obsahu problémy.

(iii) Žák ř́iká: Nerozumím tomu, proč $(-1) \cdot(-1)=1$.

Uved'te co nejvíce různých způsobů, jak tuto záležitost žákovi vysvětlit.

(Kleickmann et al., 2013: s. 102, vlastní překlad, vynechána ilustrace k otázce ii)

Podobný přístup byl zvolen i v nedávno publikované studii (Depaepe et al., 2015), která mj. porovnává (didaktické) znalosti obsahu v oblasti zlomků u budoucích učitelů na 1 . a 2. stupni ZŠ. Respondentům studie byly předloženy otevřené testové otázky, zkoumané didaktické znalosti obsahu byly rozděleny do dvou komponent:

1. znalosti žákových miskoncepcí;

2. znalosti výukových strategií, reprezentací a modelů. 
Odpovědi na testové otázky byly bodovány. Př́klady testových otázek pro jednotlivé komponenty:

1. Na obrázku jsou uvedena tři různá žákovská řešení. Pro každé řešení napište pravděpodobnou žákovu úvahu vedoucí k tomuto řešení a určete, zda je řešení správné.

2. Během hodiny zaměřené na sčítání zlomků použil učitel koláčový model na znázornění součtu $4 / 7+5 / 7$. Uved'te dva důvody, proč byste tento model v dané situaci nepoužili.

(Depaepe et al., 2015: s. 87, vlastní překlad, zkráceno, obrázky vynechány)

\section{Concept Cartoons}

V předkládané studii použijeme jako nástroj pro zkoumání didaktických znalostí obsahu kreslené obrázky zvané Concept Cartoons. Název Concept Cartoons (jako množné číslo od Concept Cartoon) vymysleli v roce 1991 Brenda Keoghová a Stuart Naylor, o dva roky později pak publikovali o Concept Cartoons jako výukové pomůcce svůj první příspěvek v odborném časopise (Keogh \& Naylor, 1993).

V rozporu s významem anglického slova cartoon ${ }^{5}$ nejsou Concept Cartoons kreslené vtipy ani obrázkové seriály, ale s obojím mají cosi společného: každý Concept Cartoon je jednoduchý kreslený obrázek znázorňující „bublinový“ rozhovor několika dětí. Děti se nacházejí v jim známém prostředí (školním či mimoškolním), zobrazená situace je převzata z každodenního života, texty v bublinách jsou stručné a používají jednoduchý jazyk. Děti prostřednictvím bublin vyjadřují svůj vlastní názor nebo reagují na názor jiného dítěte ze skupinky. Důležité je, že žádné dítě nevystupuje nadřazeně, jednotlivé názory jsou rovnocenné. V bublinách se objevují různé alternativní pohledy na zobrazovanou situaci; některé jsou správné, jiné nesprávné, u některých může být správnost nejasná nebo podmíněná určitými okolnostmi. V některých bublinách může být blíže naznačeno diskutované téma nebo nepřímo položena otázka. Jedna z bublin obsahuje místo textu otazník jako zdo̊raznění toho, že mohou existovat i jiné názory, na obrázku dosud neuvedené.

Jeden z prvních Concept Cartoons je uveden na obr. 1. Na tomto obrázku ovlivňují pravdivost jednotlivých alternativ hned dva faktory: aktuální počasí a materiál, ze kterého je kabát vyroben. Při vhodné kombinaci těchto faktorů může být pravdivá každá alternativa.

Jako výuková pomůcka jsou obrázky Concept Cartoons obvykle nabízeny žákům s otázkami: „Co si myslíš ty?", „Které z dětí na obrázku má pravdu?", „Proč?“, „Co můžeme doplnit do prázdné bubliny místo otazníku?", a žáci diskutují o odpovědích na tyto otázky.

Podobné obrázky nabízeli ve svých učebnicích pro 1. stupeň základní školy také Kittler, Koman, Kuřina a Tichá (např. Kittler, 1994; viz obr. 2), a to jako nástroj $\mathrm{k}$ překlenutí rozdílu mezi neformálním běžným jazykem a formálním jazykem matematiky.

\footnotetext{
${ }^{5}$ cartoon n. 1 karikatura, kreslený vtip; obrázkový seriál, 2 kreslený film, groteska (Fronek, 1999)
} 


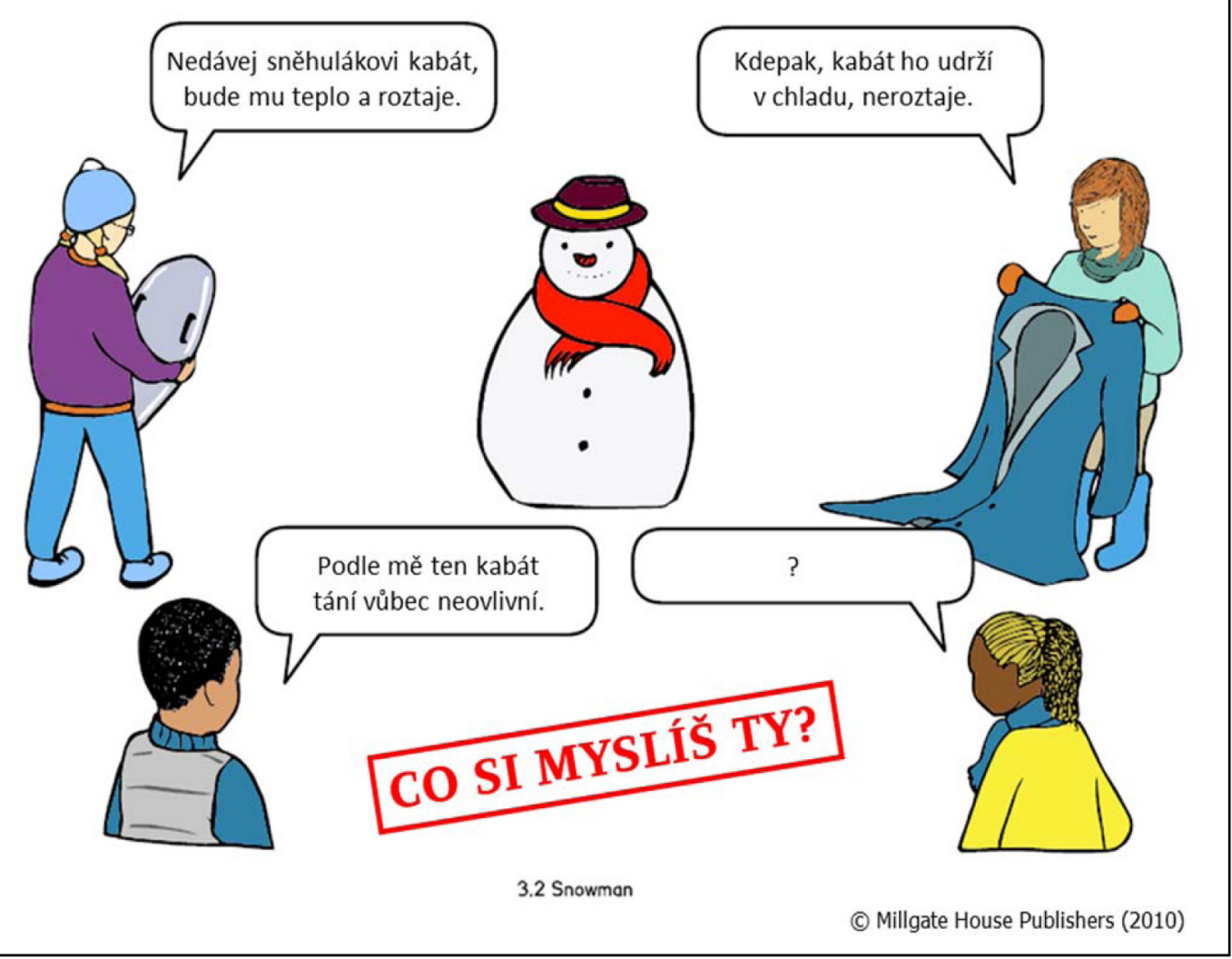

Obr. 1: Jeden z prvních Concept Cartoons; obrázek převzat od autorů Naylora \& Keoghové (2010: č. 3.2), vlastní překlad

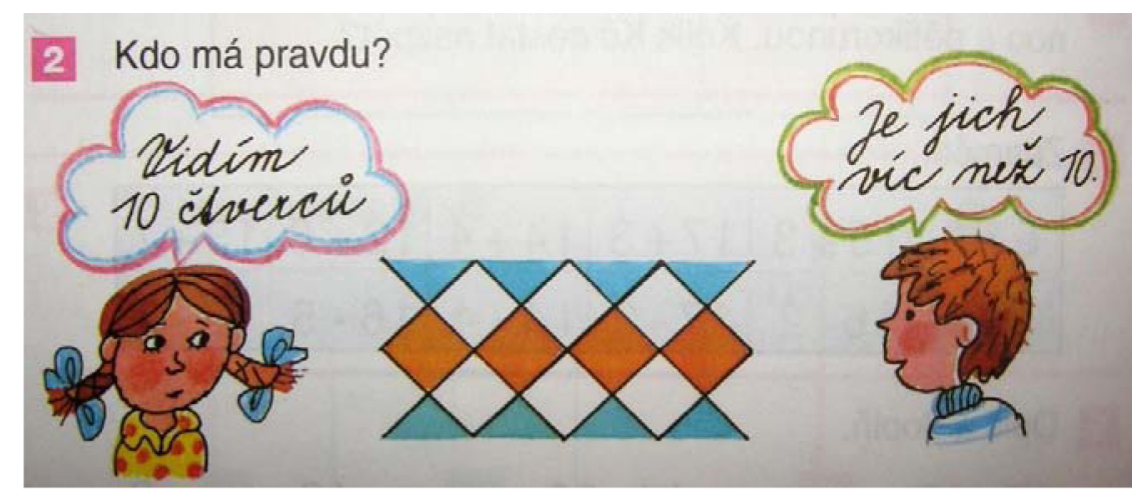

Obr. 2: Obrázek z učebnice Matematika pro 1. ročník základní školy (Kittler, 1994: s. 42)

\subsection{CONCEPT CARTOONS JAKO VÝUKOVÁ POMŮCKA V PŘÍRODOVĚDNÉM VZDĚLÁVÁNÍ}

Jak napovídá obr. 1, Concept Cartoons vznikly původně jako výuková pomůcka určená pro podporu výuky př́rodovědných předmětư ${ }^{6}$ na 1 . a 2 . stupni základních škol. Za více než 20 let své existence se ve Velké Británii staly nedílnou součástí výuky na mnoha základních školách, univerzitách (pedagogických fakultách) a v kurzech dalšího vzdělávání učitelů.

\footnotetext{
${ }^{6} \mathrm{~V}$ angličtině science teaching and learning; ve školním prostředí je science označením pro skupinu předmětů zahrnující biologii, fyziku a chemii, a to na všech stupních škol, včetně propedeutik.
} 
První větší pedagogický výzkum související s Concept Cartoons mapoval reakce žáků, budoucích učitelů a učitelů na použití Concept Cartoons ve výuce (Keogh \& Naylor, 1999). Tento výzkum ukázal většinovou pozitivní reakci žáků, zvýšení jejich motivace a lepší zapojení do výuky. Při pozorování dění ve tř́idě se ukázalo, že diskuse se zúčastňují i žáci, kteří se jinak běžně zdráhají mluvit nebo projevit svůj názor. Podle autorů studie je jedním z možných vysvětlení, že při používání Concept Cartoons nejsou žáci posuzováni učitelem, ale sami posuzují názory někoho jiného (dětí na obrázku). Pokud se později ukáže, že názor byl nesprávný, žák může svést vinu za chybu na dítě z obrázku.

Jiná studie (Naylor, Keogh \& Downing, 2007) se věnovala podobě diskuse a kvalitě žákovských argumentů a jako nejvhodnější formu použití Concept Cartoons pro argumentaci vyhodnotila diskusi v malých skupinkách. Tato studie prokázala, že nesoulad v názorech, který panuje mezi dětmi na obrázku, povzbuzuje žáky k účasti $\mathrm{v}$ diskusi a $\mathrm{k}$ přednesení vlastního názoru a že takto iniciovaná diskuse může mít podobu smysluplné argumentace.

Podrobnosti o dalších pedagogických výzkumech souvisejících s použitím Concept Cartoons ve výuce př́rodovědných předmětů lze nalézt v souhrnném přehledu (Naylor \& Keogh, 2013).

Česká odborná veřejnost se s výukovou pomůckou Concept Cartoons poprvé blíže seznámila díky Edu van den Bergovi, který se zúčastnil několika projektů na podporu přrírodovědného vzdělávání realizovaných v ČR a podělil se zde o své zkušenosti s využitím Concept Cartoons při plánování laboratorních pokusů (2013, 2014). Na něj navázala Hejnová (2014) se svou publikací o využití Concept Cartoons v hodinách fyziky.

V přírodovědné výuce se využívají i jiné typy vzdělávacích komiksů, jejich přehled uvádějí Trnová a kol. (2016).

\subsection{Concept Cartoons Jako diagnostickÁ POMŮCKA V PŘ́́RODOVĚDNÉM VZDĚLÁVÁNÍ}

Brenda Keoghová a její kolegové použili Concept Cartoons také jako diagnostickou pomůcku, a to pro zjištění úrovně přírodovědných znalostí vysokoškolských studentů na začátku prvního roku studia učitelství (Keogh, Naylor, Boo \& Feasey, 1999). Každému ze studentů byla předložena sada patnácti Concept Cartoons se společnými otázkami: „Které děti mají pravdu?“ a „Proč?“. Studenti na otázky odpovídali písemně, odpovědi byly bodovány; hodnoceno bylo celkové porozumění zobrazené situaci a správnost argumentů (S. Naylor, osobní konzultace, 13. 5. 2014). Studenti s nízkým bodovým ziskem byli v prvním ročníku studia povinni absolvovat doplňující prř́rodovědný kurz.

Ve své studii využila Concept Cartoons i Michaela Minárechová (2014) - jejich prostřednictvím zjištovala žákovské představy o vybraných přírodních jevech.

\subsection{CONCEPT CaRToOns Jako vÝuková POMŮCKA V MATEMATICKÉM VZDĚLÁVÁNÍ}

Poté, co se Concept Cartoons osvědčily v přrírodovědném vzdělávání, se začaly ve Velké Británii používat i při výuce matematiky (Dabell, 2008; Dabell, Keogh \& Naylor, 2008). Podobně jako v případě přírodovědných Concept Cartoons obsahují bubliny matematicky zaměřených Concept Cartoons rozličné alternativní pohledy 
na zobrazenou situaci. Obvykle jsou tyto pohledy inspirovány různými interpretacemi pojmů souvisejících se zobrazenou situací, různými způsoby matematizace zobrazené situace, různými cestami hledání řešení zobrazeného problému, různými způsoby interpretace nalezených řešení nebo různými podmínkami, které mohou zobrazenou situaci ovlivňovat.

Na téma Concept Cartoons jako výukové pomůcky v matematickém vzdělávání nebyl proveden žádný větší pedagogický výzkum, autoři Concept Cartoons předpokládají, že výsledky vzešlé z velkých přírodovědných výzkumů (zvýšení motivace a lepší zapojení žáků do výuky, podpora argumentace apod.) jsou obecného charakteru a nezávisí na konkrétním vyučovacím předmětu (S. Naylor, osobní konzultace, 13. 5. 2014).

\subsection{CONCEPt CARTOONS JAKO NÁSTROJ PRO ZKOUMÁNí DIDAKTICKÝCH ZNALOSTÍ OBSAHU}

Při prvním setkání s Concept Cartoons (v roce 2012) nás kromě jejich významu pro výuku žáků zaujala i skutečnost, že jednotlivé obrázky znázorňují různé názory dětí na nějakou situaci. Svým způsobem tak imitují rozličné situace, jež mohou nastat ve třídě. Odtud vzešel prvotní nápad použít Concept Cartoons pro zkoumání znalostí, jež učitel uplatňuje v podobných situacích.

Dalším impulsem pro volbu Concept Cartoons jako výzkumného nástroje byla šetření ukazující, že obrázky Concept Cartoons při použití ve třídě podněcují žáky (i ty, kteří se běžně zdráhají projevit svůj názor) k účasti na diskusi a $\mathrm{k}$ přednesení vlastního názoru (viz oddíl 2.1). Tato šetření naznačují, že při použití obrázků Concept Cartoons by nemusely nastat problémy s neochotou respondentů odpovídat na otázky a s nedostatkem získaných dat. Je však otázkou, zda se tato vlastnost Concept Cartoons projeví i při jejich použití pro sběr dat v písemné podobě.

Kompozice obrázků Concept Cartoons je podobná kompozici některých testových otázek používaných pro zkoumání didaktických znalostí obsahu: podobně jako v bublinách se nabídka různých odpovědí žáků a požadavek na jejich posouzení objevuje v testových otázkách zkoumajících znalosti žákových poznávacích procesů (komponenta (ii) ve studii Kleickmann et al., 2013; komponenta (1) ve studii Depaepe et al., 2015), požadavek doplnit do prázdné bubliny nějaké alternativní řešení je podobný testovým otázkám zkoumajícím znalosti učebních úloh (komponenta (i) ve studii Kleickmann et al., 2013).

Originálním obrázkům Concept Cartoons však oproti testovým otázkám chybí dotazy na pravděpodobné žákovy úvahy a na možné zdroje žákova neporozumění, a také požadavky na poskytnutí vysvětlení, jež by bylo žákovi srozumitelné - tyto nedostatky originální podoby obrázků Concept Cartoons snad bude možné vyřešit rozšǐřením sady otázek předkládaných spolu s obrázky. Oproti testovým otázkám dále obrázkům chybí požadavky na posouzení činnosti jiného učitele, ale ty jsou ve stávající podobě prostředí Concept Cartoons obtížně realizovatelné.

Z důvodu výše uvedených nejasností souvisejících s možností využití Concept Cartoons pro zkoumání didaktických znalostí obsahu u budoucích učitelů 1. stupně bude vlastnímu výzkumnému šetření předcházet přípravná studie. 


\section{Př́́PRAVNÁ STUdie}

V rámci přípravné studie jsme rozšiřili sadu otázek předkládaných s obrázky Concept Cartoons o otázky na pravděpodobné žákovy úvahy, na možné zdroje žákova neporozumění a o požadavky na poskytnutí vysvětlení žákovi. Ověřovali jsme, jestli a jaké Concept Cartoons spolu s rozššřrenou sadou otázek umožňují získat dostatečné množství relevantních dat pro zkoumání didaktických znalostí obsahu.

\subsection{VÝZKUMNÁ OTÁZKA Př́́PRAVNÉ STUDIE}

„Jaká podoba prostředí Concept Cartoons je vhodná pro zkoumání didaktických znalostí obsahu?“

\section{2 ÚČASTNÍCI PřÍPRAVNÉ STUDIE}

Studie se zúčastnilo 127 studentů různých ročníků vysokoškolského studia učitelských oborů Učitelství pro 1. stupeň ZS̆ a Učitelství pro 2. stupeň ZŠ, v prezenční i kombinované formě; $55 \mathrm{z}$ nich již mělo absolvovaný aspoň jeden semestr kurzu didaktiky matematiky. Nikdo z účastníků této studie nebyl účastníkem hlavního výzkumného šetření.

\subsection{Organizace PŘíPRAVNÉ STUdie}

Přípravná studie proběhla ve dvou fázích.

\subsubsection{PRVNí FÁze Př́́PRAVNÉ STUdie}

Z originální sady Concept Cartoons (Dabell, Keogh \& Naylor, 2008) byly v první fázi vybrány 4 obrázky z oblasti číselných oborů (přirozená čísla, desetinná čísla a zlomky) v rozsahu odpovídajícím učivu 1. stupně ZŠ. Obrázky byly vybrány tak, aby se lišily typem zobrazené situace (2 školní a 2 mimoškolní aktivity), typem textu v bublinách (bubliny s výsledky, bubliny s postupy řešení a výsledky, bubliny s radami chybujícímu žákovi) a počtem bublin se správnými odpověd’mi. Studentům byly tyto Concept Cartoons předloženy ve formě pracovního listu (každý obrázek na zvláštním listu papíru) s následujícími pokyny:

U každého obrázku okomentujte jednotlivé názory v bublinách takto:

1. Napište, se kterým názorem nejvíce souhlasite, tj. který je Vám nejbližší.

2. Napište, se kterým názorem rozhodně nesouhlasite.

3. Rozhodněte, které názory jsou správné a které chybné. Své rozhodnutí zdưvodnète.

4. U chybných názorů se pokuste odhalit, proč vznikly.

5. Vysvětlete autorům chybných názori̊, kde udělali chybu. Poradte jim, jak tuto chybu napravit.

6. Vymyslete text, který by mohl být $v$ bublině s otazníkem - nezáleži na tom, jestli bude správný, nebo chybný. Mưže souviset s nějakým jiným správným řě̌enim/postupem nebo nějakou dalši chybnou úvahou.

Studenti pracovali samostatně, na vyplnění listů měli cca 80 minut.

Originální Concept Cartoons nemají děti na obrázcích nijak pojmenované (podobně jako na obr. 1). Při vyplňování pracovních listů s první skupinou studentů se 


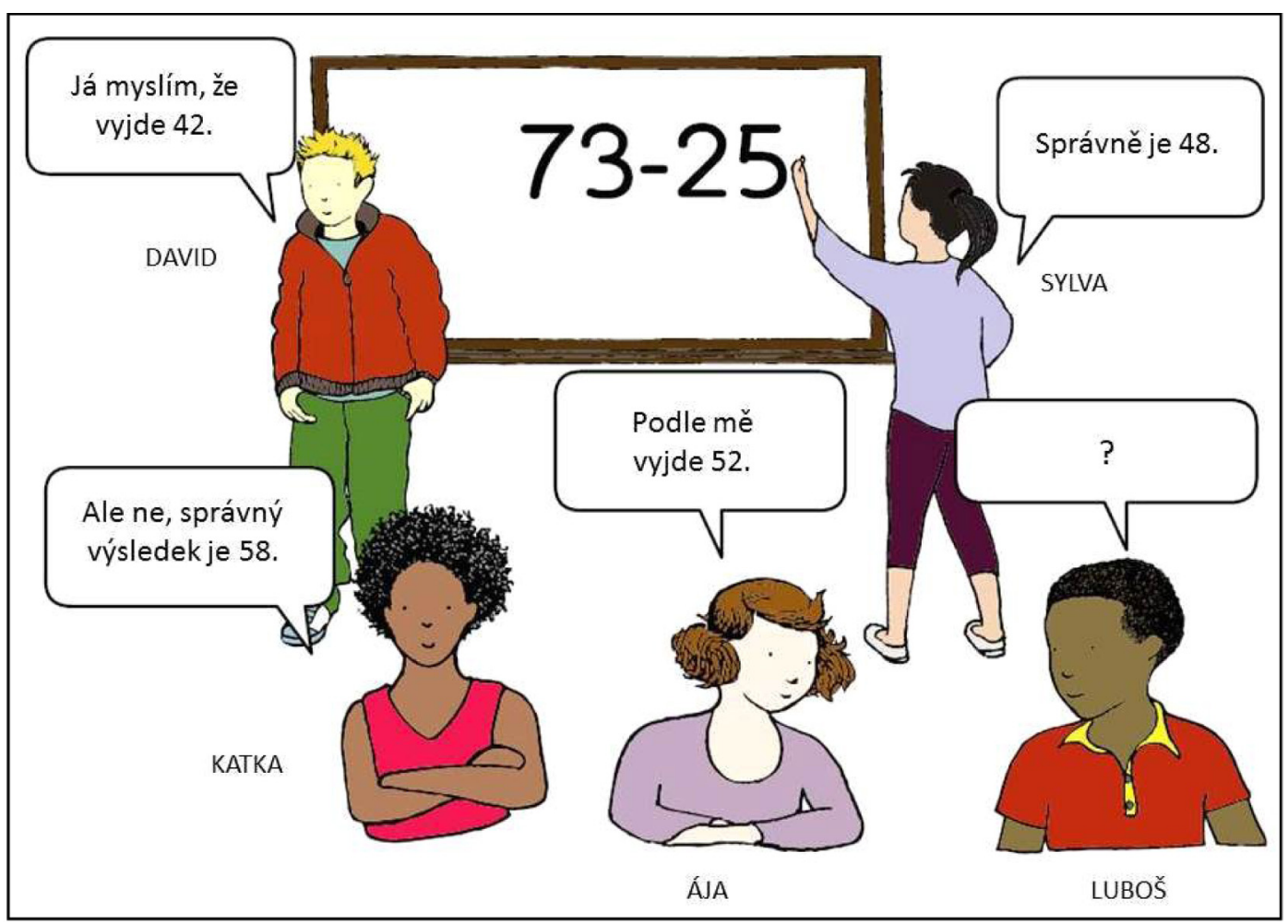

Obr. 3: Concept Cartoon s výsledky, nově vytvořený; obrázek prázdné tabule a dětí s prázdnými bublinami byl převzat od Dabella, Keoghové \& Naylora (2008: č. 2.12)

však někteří studenti ozvali, že neví, jak se mají při vyplňování listů na jednotlivé děti z obrázků odkazovat. Nechali jsme je tedy doplnit k dětem písmena $(A, B, \ldots)$ a pro další skupiny studentů jsme již připravili obrázky se jmény jako na obr. 3 .

Data z pracovních listi̊ jsme zpracovali kvalitativně, za použití otevřeného kódování (Švaříček \& Šed’ová, 2014), soustředili jsme se na projevy znalostí obsahu a didaktických znalostí obsahu.

Podrobný rozbor části výsledků první fáze přípravné studie související se studenty druhého a třetího ročníku oboru Učitelství pro 1. stupeň ZŠ lze nalézt v (Samková \& Hošpesová, 2015).

\subsubsection{Tvorba Concept Cartoons pro druhou fázi Př́́pravné Studie}

Pro druhou fázi přípravné studie jsme vytvořili 14 vlastních obrázků - některé vznikly pouhou úpravou textu jedné či více bublin v originálních Concept Cartoons (Dabell, Keogh \& Naylor, 2008), jiné zcela nově. Přibyly i nové typy textu v bublinách, např. vyjádření se k podmínkám platnosti tvrzení, vyjádření se k počtu řešení, odkaz na neuvedené schéma.

Při tvorbě nových Concept Cartoons jsme do bublin umistovali obvyklé i méně obvyklé představy žáků, rozličné postupy řešení (správné i chybné), někdy i záměrně připravené věrohodně vypadající mylné názory (viz Samková \& Tichá, 2015). Inspirovali jsme se vlastními zkušenostmi z výuky, zkušenostmi kolegů i výsledky pedagogických výzkumů (Hejný \& Stehlíková, 1999; Kořínek, 1965; Tichá \& Macháčková, 2006; Ryan \& Williams, 2011; Hansen, 2011; aj.).

Concept Cartoon na obr. 3 byl např. vytvořen na základě výzkumu Bany, Farrella a McIntoshe (1995), jeho tvorba je podrobně popsána v příspěvku autorek Samkové, Tiché a Hošpesové (2015). 


\subsubsection{DRUHÁ FÁZE PŘÍPRAVNÉ STUDIE}

Pracovní listy s nově vytvořenými obrázky jsme studentům předkládali za stejných podmínek jako v první fázi (viz 3.3.1). Data jsme opět zpracovali kvalitativně.

\subsection{ZÁVĚRY PŘÍPRAVNÉ STUDIE}

Porovnáním výsledků z první a druhé fáze přípravné studie se ukázalo, že pro zkoumání didaktických znalostí obsahu je vhodné na obrázcích Concept Cartoons kombinovat bubliny stručně naznačující postup řešení a výsledek (např. jako na obr. 4) a bubliny uvádějící pouze výsledky (např. jako na obr. 3).

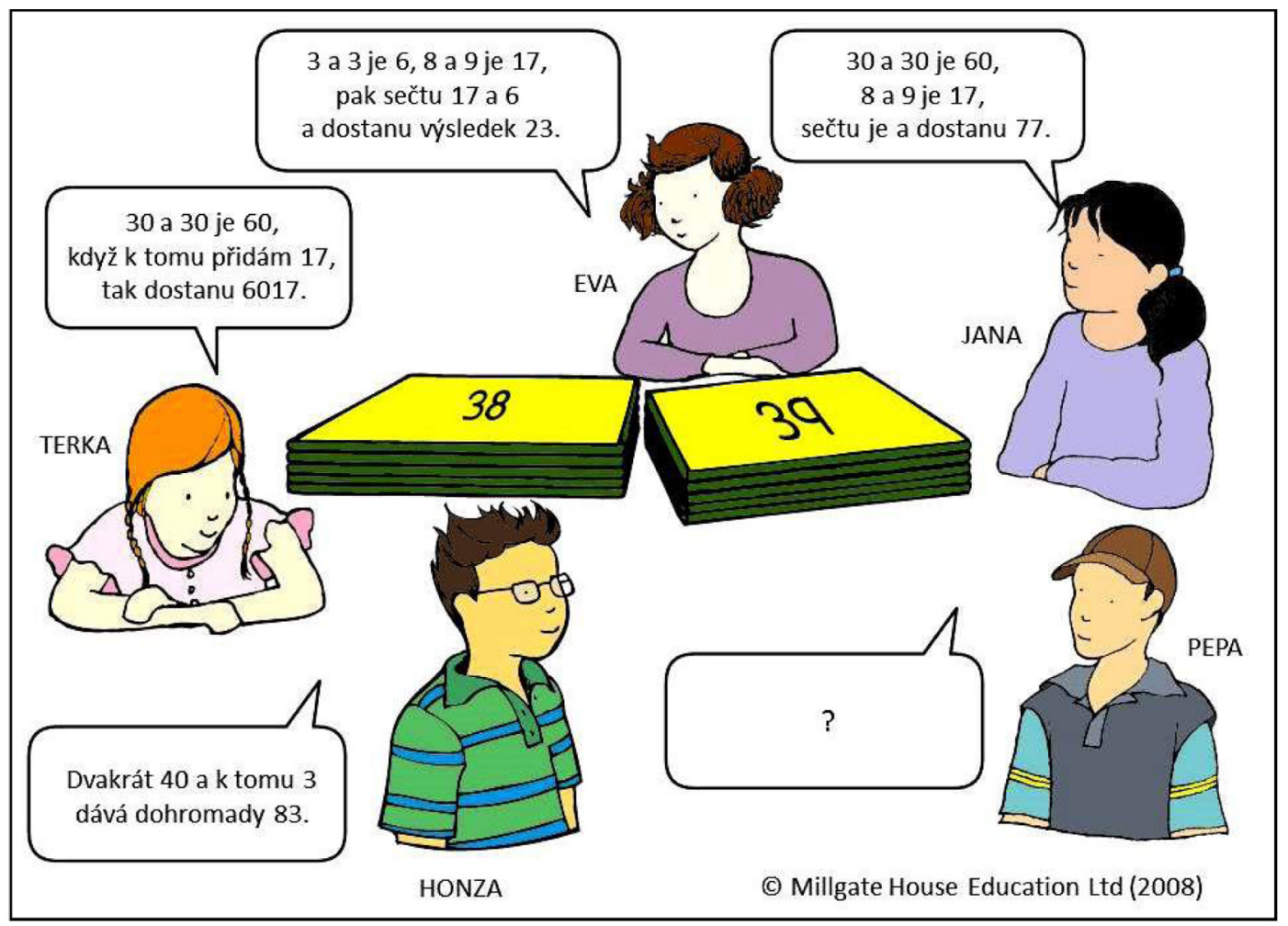

Obr. 4: Concept Cartoon s postupy a výsledky; převzato z Dabella, Keoghové \& Naylora (2008: č. 2.3), přidána jména, vlastní překlad

U bublin prvního typu mohou respondenti komentovat jak postupy, tak i výsledky. Mohou hledat chyby $\mathrm{v}$ postupech vedoucích $\mathrm{k}$ chybným výsledkům, ale i chyby v postupech vedoucích ke správným výsledkům.

U bublin druhého typu mohou respondenti komentovat pouze výsledky, což zjednodušuje rozhodování u správných výsledki̊, ale komplikuje rozhodování u chybných výsledků. Pro odpověd’ na otázky 4 a 5 se tak respondent musí pokusit odhadnout, jaké chybné úvahy nebo postupy by mohly uvedenému chybnému výsledku předcházet.

Originální Concept Cartoons mají na každém obrázku vždy bubliny jednoho typu, podrobnější rozbor dat nás však upozornil na možné obtíže související s obrázky obsahujícími pouze bubliny s výsledky: pokud byl takový obrázek založen na výpočtu (např. jako obr. 3), dost často se stávalo, že respondenti pouze porovnali výsledek výpočtu s čísly v bublinách a neprojevili snahu hledat postupy skryté za těmito čísly. Na pracovních listech pak nebyla téměř žádná relevantní data k didaktickým znalostem obsahu. Mezi obrázky tohoto typu předkládanými v rámci přípravné studie jsme našli pouze jeden, u kterého problémy s nedostatkem dat nevznikly - pravděpodobně díky tomu, že výsledky v bublinách byly všechny zapsány 
pouze pomocí číslic 1 a 0 , a tato neobvyklá kompozice zaujala respondenty natolik, že se rozhodli bublinám více věnovat (podrobněji o tomto obrázku viz Samková \& Hošpesová, 2015).

Během př́ípravné studie se potvrdila rozlišovací funkce otázek 3 až 5: studenti, kteří ještě neabsolvovali žádný kurz didaktiky matematiky, pro všechny tři otázky poměrně často používali jednu společnou odpověd', ale u studentů s absolvovaným kurzem didaktiky matematiky jsme tento jev nezaznamenali.

Otázky 1 a 2 jsme původně do sady zařadili s úmyslem zjištovat spontánní (okamžité) reakce na názory v bublinách. Na rozdíl od otázek 3 až 5 , které vedou spíše k promyšleným odpovědím, otázky 1 a 2 nevyžadují žádné zdůvodnění. V souvislosti s nepředvídanými situacemi ve třídě považujeme okamžité reakce učitele na názory žáků za velice důležité. Data náležející k těmto otázkám však prokazovala poměrně vysokou míru škrtání a přepisování - nedalo se tak s jistotou říci, zda respondenti dodržovali pořadí otázek, zdali se někteří po zodpovězení otázky 3 nevrátili k otázkám 1 a 2 a odpovědi na ně nepřepsali. Podobně by se nedaly odhalit ani případy, kdy by respondenti jako první řešili otázku 3 a až poté se vrátili k otázkám 1 a 2 . Zajistit dodržování správného pořadí vyplňování odpovědí tak, aby to nepůsobilo rušivě, by ale bylo organizačně náročné. Po zvážení všech pro (mezi odpověd'mi na tyto dvě otázky se objevilo několik velice zajímavých reakcí) a proti (výše uvedené nejasnosti ohledně pořadí vyplňování odpovědí) jsme se nakonec rozhodli obě otázky v sadě ponechat. Odpovědi na ně však spíše než jako spontánní reakci budeme chápat jako doplněk k odpovědi na otázku 3.

Pro vlastní výzkum jsme na základě přípravné studie vybrali čtyři originální Concept Cartoons (např. obr. 4) a čtyři jsme nově vytvořili (např. obr. 5). Z těchto obrázků bylo pět na téma přirozená čísla, dva na téma zlomky a jeden na téma desetinná čísla.

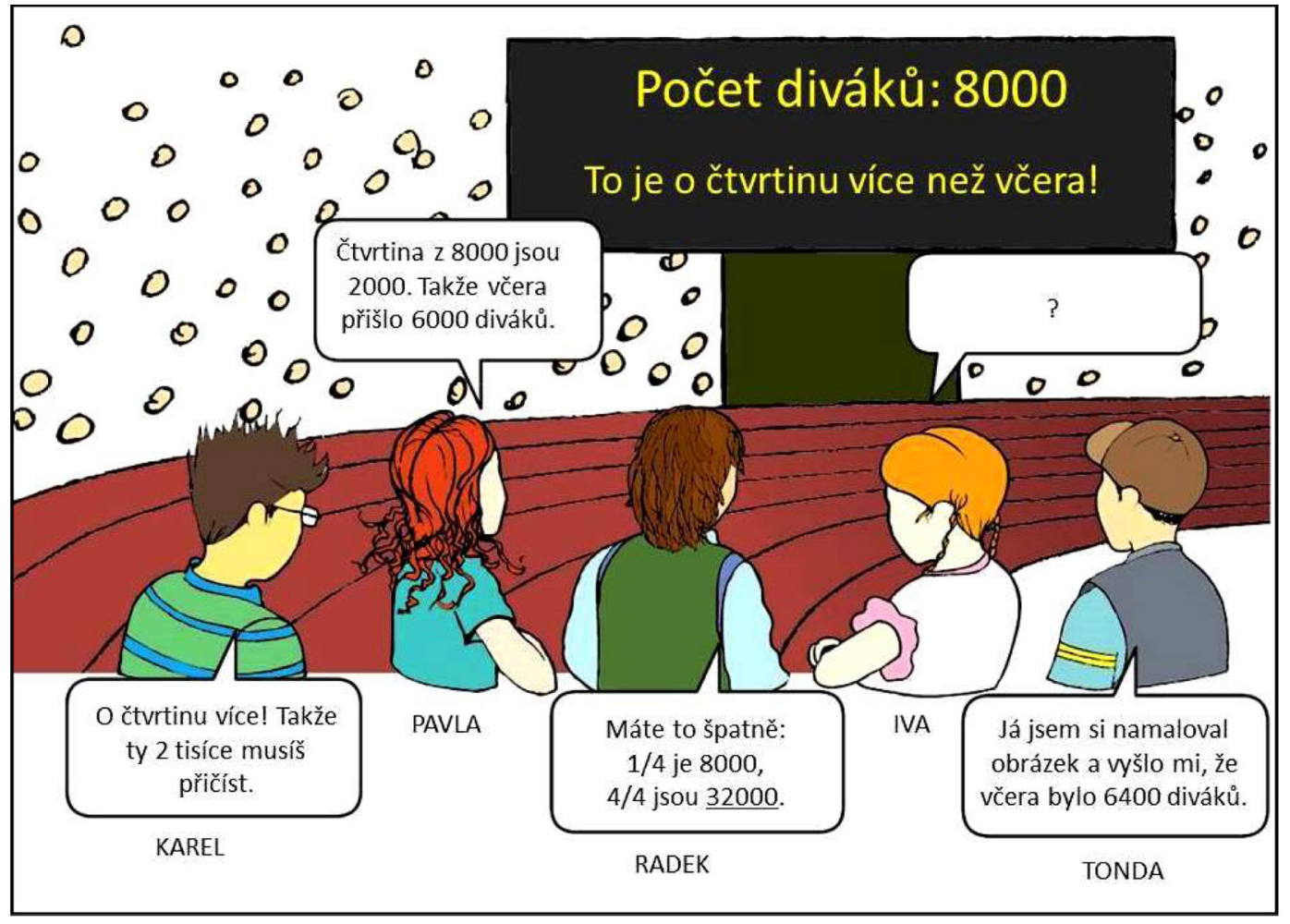

Obr. 5: Nově vytvořený Concept Cartoon, inspirovaný úlohou z publikace Řídké et al. (2015); obrázek stadiónu s prázdnou cedulí a dětí s prázdnými bublinami převzat od Dabella, Keoghové \& Naylora (2008: č. 1.2) 


\section{VLASTNÍ VÝZKUMNÉ ŠETřENí}

\subsection{VÝZKUMNÁ OTÁZKA}

„S jakými didaktickými znalostmi obsahu v oblasti číselných oborů vstupují studenti magisterského oboru Učitelství pro 1. stupeň ZŠ do kurzo̊ didaktiky matematiky?"

\section{2 ÚČASTNÍCI VÝZKUMU}

Účastníky výzkumu byli studenti 2. ročníku pětiletého magisterského studia Učitelství pro 1. stupeň ZŠ. Výzkumu se zúčastnilo 29 prezenčních studentů - celý studijní ročník. Během druhého ročníku studia tito studenti absolvovali kurz aritmetiky zaměřený na úvod do logiky, úvod do množinové logiky a na číselné obory. Kurzy z didaktiky matematiky budou studenti navštěvovat až v následujícím školním roce.

Všichni sledovaní studenti přišli na vysokou školu bezprostředně po maturitě, bez zkušeností s vlastní výukou. Nezávisle na našem výzkumu se v prvním semestru druhého ročníku vysokoškolského studia zúčastnili kurzu obecné didaktiky a týdenní náslechové praxe, ve druhém semestru týdenní asistentské praxe a úvodních kurzů didaktiky českého jazyka, př́rodovědy a tělesné výchovy.

Žádný z účastníků výzkumu nebyl účastníkem přípravné studie.

\subsection{ORganizACE VÝZKUMU}

Sběr dat proběhl ve dvou fázích, uprostřed a po skončení školního roku. V každé fázi byly studentům předloženy pracovní listy se čtyřmi obrázky Concept Cartoons, se stejnými pokyny a časovými dispozicemi jako v př́pravné studii (viz oddíl 3.3.1). Předkládané Concept Cartoons byly vždy zaměřeny na témata, která studenti na kurzech aritmetiky již měli probraná.

Data z pracovních listů jsme zpracovali kvalitativně, s využitím otevřeného kódování a konstantní komparace (Gavora, 2010; Švaříček \& Šed’ová, 2014). Nejprve bylo provedeno otevřené kódování veškerého materiálu. Vzniklé kódy byly rozděleny do kategorií:

A. rozpoznání správného/chybného tvrzení v bublině (např. kódy „správný názor považuje za chybný“, „nedokáže se rozhodnout o správnosti“, „chybí vyjádření k některé bublině“");

B. vlastní respondentovy chyby a omyly, které se vyskytly v rámci vysvětlování a rad (např. kódy „plete si celek a část", „chybný obrázek“, „neporozuměl zadání úlohy“);

C. rozpoznání postupů $\mathrm{v}$ bublinách a jejich podstaty (např. kódy „neuvedena přičina chyby“, „porovnává svůj výsledek a bublinu“, „odhalil chybný krok“, „jasné vysvětlení“, „absurdní vysvětleni“", „nerealistická představa“, „př́liš obecné“, „neúplná identifikace prř́činy“);

D. rozlišování mezi identifikací chyby, její příčinou a její nápravou (např. kódy „rozlišuje IPN“, „nerozlišuje IPN“, ,jedna odpověd’ pro otázky $3,4,5$ “);

E. prázdná bublina (např. kódy „nevyplněno“, „alternativní postup správný“, „alternativní postup chybný“, „nerealistické představy“, „3 a 3 je 33, 8 a 9 je $\left.899^{\prime \prime}\right){ }^{7}$

\footnotetext{
${ }^{7}$ Kurzíva označuje kód, jehož název je citací nějakého úryvku.
} 
F. největší (ne)souhlas (např. kód „nejvíc nesouhlasí s Honzou“);

G. formální zpracování (např. kódy „pečlivě dodržuje členění podle bodů“, „odpovědi píše vedle bublin“, „používá slovo číslo místo číslice“, „30+30 =60+17 =

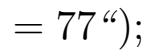

H. orientace v obrázku a kontextu (např. kódy „nespojila si bubliny se jmény“, „považuje za správné dva různé výsledky početního příkladu“);

I. zatím nezařazeno (např. kódy „zajímavé“, „nejasné“).

Byla použita metoda konstantní komparace, data byla opakovaně pročítána a v případě potřeby opatřována novými kódy, kódy byly opakovaně porovnávány s daty i mezi sebou, upravovány a přerovnávány. Pro lepší orientaci byl každý kód opatřen znaménkem „,+“ nebo „--" podle toho, jestli jemu příslušné sekvence považujeme za pozitivní nebo negativní z hlediska (didaktické) znalosti obsahu. Během procesu konstantní komparace byl přeorganizován i seznam kategorií:

- kódy z kategorie I byly průběžně upravovány a umistovány do jiných kategorií, až byla nakonec kategorie I vyprázdněna a zrušena;

- kategorie H byla zrušena a její kódy rozděleny mezi kategorie B a G;

- kategorie G byla nakonec také zrušena a její kódy bud' vyřazeny (např. kód „nespojila si bubliny se jmény“), přesunuty do kategorie D (např. kód „pečlivě dodržuje členění podle bodů"), nebo přesunuty do kategorie B (např. kód „používá slovo číslo místo číslice“);

- během jedné z úvodních fází procesu komparace vznikla také nová kategorie sdružující nově vzniklé kódy související s radami dětem (např. kódy „pěkně formulovaná rada“, „příliš obecná rada“, „rada jako popis toho, co je špatně“), ale časem byla zrušena z důvodu př́lišné provázanosti s kategoriemi $\mathrm{C}$ a $\mathrm{D}$; její kódy byly přsesunuty do těchto dvou kategorií, některé duplicitně.

Do další fáze zpracování dat tak zůstaly kategorie $\mathrm{A}$ až F.

Kódy byly komparovány v rámci jednotlivých Concept Cartoons i mezi jednotlivými respondenty. Při druhém způsobu se opakovaně negativně projevovala nesourodost dat daná různou odezvou na různé kompozice Concept Cartoons. Pro lepší přehlednost struktury dat a kódů jsme tak systém obohatili o novou kategorii kódů - o nové kódy vyjadřující se ke kompozici obrázku (typ textů v bublinách, počet bublin se správnou odpovědí, počet řešení zobrazené úlohy, typ a množství chyb v bublinách apod.). Následné komparace byly prováděny v rámci Concept Cartoons se stejnými kompozičními kódy.

Jako kategorie s nejvyšší nasyceností dat byly identifikovány kategorie A, C a E, tedy kategorie související s tou částí didaktických znalostí obsahu, která zahrnuje:

- schopnost znát a rozpoznat různé běžné strategie řešení;

- schopnost znát a rozpoznat běžné žákovské miskoncepce a jejich pravděpodobné zdroje.

\section{ZJIŠTĚNÍ VÝZKUMU}

Zjištění výzkumu nejprve představíme v obecné podobě, poté je budeme ilustrovat konkrétními datovými úryvky. 


\subsection{OBECNÁ ZJIŠTĚNí}

Přestože respondenty výzkumu byli studenti, kteří se ještě nezúčastnili žádného kurzu didaktiky matematiky, tak získaná data odhalila několik respondentů s didaktickými znalostmi obsahu na vysoké úrovni. Tito respondenti na pracovních listech

- uváděli různé alternativní postupy řešení (např. respondenti $\mathrm{S} 4 / \mathrm{Pepa}^{8}, \mathrm{~S} 5 / \mathrm{Pe}-$ pa, S10/Pepa), i ty „chytré“, které výhodně využívají nějakých specifických souvislostí (např. S3/Pepa, S26/Pepa);

- poznávali různé žákovské miskoncepce (např. S9/Eva, S11/Honza, S16/Honza, S19/Honza, S30/Pavla, S31/Pavla+Radek);

- uměli nalézt chybu v postupu a jasně zdůvodnit, proč k ní došlo a jak je možné ji opravit (např. S3/Honza, S4/Pavla+Karel+Radek, S9/Honza, S16/Honza, S19/Honza);

- měli snahu hledat v chybných postupech správné kroky a na těch postavit rady dětem, tj. jejich rady byly konstruktivní (např. S3/Honza, S3/Eva, S9/Honza, S16/Honza, S19/Honza);

- vhodně využívali vizualizaci (S2/Tonda, S4/Tonda, S24/Tonda, S22/Tonda);

- dokázali správně provést zkoušku u úlohy, kterou sami neřešili, a dětem s chybnou odpovědí dokázali vysvětlit, proč jejich názor nemůže být správný (např. S6/Tonda+Pavla+Radek, S10/Pavla+Karel+Radek).

Zároveň data odhalila i respondenty s nízkou úrovní didaktických znalostí obsahu. Tito respondenti:

- jako možné alternativní žákovské postupy řešení nabízeli nerealistické mylné představy (např. S11/Iva, S29/Iva);

- jako možná vysvětlení neznámých postupů nabízeli nerealistické mylné představy (např. S1/Tonda, S21/Tonda) nebo představy zcela nesouvisející se zadáním úlohy (např. S15/Tonda);

- nesnažili se nebo nebyli schopni v chybných postupech hledat správné kroky, v důsledku toho byly jimi určené příčiny chyb a jejich rady př́liš obecné (např. S13/Eva, S17/Honza);

- místo konstruktivních oprav postupu, který si zvolilo dítě, nutily dítě do jiného, „Svého" postupu (např. S18/Eva);

- měli tendenci rozhodně odmítat postupy, které sami nepochopili (např. S12/ Tonda) nebo které jim připadaly moc složité (např. S11/Honza).

Někteří respondenti ve svých odpovědích vykazovali snahu rozlišovat mezi identifikací chyby, přičinou chyby a nápravou chyby. Všichni byli v této snaze poměrně úspěšní. Výhradně se jednalo o respondenty, u kterých jsme i v jiných ohledech odhalili vyšší úroveň didaktických znalostí obsahu (např. S4/Pavla+Karel+Radek, S9/Honza, S19/Honza).

Ostatní respondenti (podobně jako v přípravné studii tvořili většinu ze sledovaného vzorku) poskytovali odpovědi, které mezi identifikací, příčinou a nápravou nerozlišovaly (např. S3/Honza, S12/Tonda, S16/Honza).

U žádného z respondentů nevznikl problém s nedostatkem relevantních dat.

\footnotetext{
${ }^{8}$ Odkaz na datový úryvek uvedený v odd. 5.2: číslo respondenta/jméno dítěte, na které respondent $\mathrm{v}$ úryvku reaguje.
} 


\subsection{DATOVÉ ÚRYVKY}

Výše uvedená zjištění nyní podrobně doložíme konkrétními úryvky z pracovních listů. Pro tento účel jsme vybrali data náležející ke dvěma Concept Cartoons, na kterých:

- většina bublin obsahuje postupy a výsledky;

- právě jedna bublina je správně (prázdnou bublinu nepočítáme);

- úloha má právě jeden správný výsledek.

První z obrázků je založen na úloze o sčítání dvou dvouciferných čísel. Početní úloha byla pro respondenty snadná, všichni správně určili, které výsledky v bublinách jsou správné a které chybné.

Druhý obrázek je založen na slovní úloze se zlomky. Tato úloha byla obtížnější, většina respondentů nebyla schopna určit bublinu se správným výsledkem.

Pro lepší přehlednost a srozumitelnost prezentovaných dat budeme datové úryvky třídit podle jednotlivých bublin, na které respondenti v úryvcích reagovali. Přepisy z vyplněných pracovních listů budeme uvádět ve tvaru:

číslo respondenta číslo otázky odpověd’ nebo část odpovědi na tuto otázku

Pokud respondent své odpovědi nečlenil podle čísel otázek, je číslo otázky v přepisu vynecháno.

\subsubsection{CONCEPT CARTOON NA TÉMA SČÍTÁNí DVOUCIFERNÝCH ČÍSEL (OBR. 4)}

Tento Concept Cartoon je překladem originálního obrázku (Dabell, Keogh \& Naylor, 2008: č. 2.3). Velice se osvědčil v přípravné studii, a tak jsme ho nezměněný zařadili i do vlastního výzkumu.

Tématem tohoto obrázku je sčítání do 100, konkrétně početní příklad $38+39$. Obsah bublin byl vytvořen na základě jednoho obvyklého, jednoho méně obvyklého a jednoho tvưrčího žákovského postupu pro pamětné sčítání (více o různých žákovských postupech a miskoncepcích souvisejících s tímto tématem uvádí např. Hošpesová, 2003; Department for Education [DfE], 2010; Hansen, 2011).

Jedním z obvyklých postupů bývá rozklad na desítky a jednotky, desítky jako první, tj. posloupnost myšlenkových kroků $30+30=60,8+9=17,60+17=$ $=77$. Méně obvyklý je postup sčítající desítky zvlášt́ a jednotky zvlášte, opět desítky jako první, tj. $3+3=6,8+9=17,6$ desítek $+17=77$. Př́́kladem tvůrčího postupu je využití blízkosti obou čísel ke stejné desítce (kombinace dvojí kompenzace a dvojnásobku), tedy např́klad posloupnost myšlenkových kroků $2 \cdot 40=80$, $40-38=2,40-39=1,2+1=3,80-3=77$.

Do jedné bubliny byl vložen postup správný, do ostatních postup s chybou v některém kroku.

\section{HONZA}

Vysokou hustotu kódů souvisejících s didaktickými znalostmi obsahu vykazovaly reakce na Honzovu bublinu obsahující tvưrčí postup s chybou v posledním kroku.

Někteři respondenti Honzův postup dokázali ocenit a upozornili ho na chybu v posledním kroku:

S3 Honza - Fajn nápad, ale zapomněl, že při vytvoření dvou čtyřicítek zvýšil jedno číslo o 2 a druhé o 1 (celkem o 3 ), proto je musí od $80(40+40$, tj. $2 \cdot 40)$ odečíst, nikoliv číslo ještě zvyšovat. 
S16 Honza také zvolil správný postup, ale v posledním kroku udělal chybu, kdy 3 přičetl, místo odečetl.

Vysvětlení: Když přidá do jedné 402 navíc a do druhé 1 navíc, potom tato čísla musí od výsledku odečíst.

S19 1) Nejvíce souhlasím s názorem Honzy (kdyby byl správně)

4) Honza si vypočítal součet nejbližších desítkových čísel, ale rozdíl neodečetl, ale přičetl.

5) Honzo, sčítal jsi větší čísla než pưvodní, musíš tedy rozdíl odečíst, ne přičíst.

Část respondentů Honzu označila jako toho, s kým nejvíce nesouhlasí. A to i přesto, že jeho postup a chybu v něm dokázali odhalit i zdůvodnit:

S9 2) S Honzou.

4) Honza - číslo 3 měl od celkového součtu odečíst (ne přičíst).

5) Honza - musím si uvědomit, že do 40 mi chybí 2 a do další $40 \mathrm{mi}$ chybí 1 (tzn., že nemám celé 40ky a musím od nich odečíst to, co mi chybí)

S11 Honza - mohl by si udělat $2 \times 40$, ale pak tu trojku by si musel odečíst a ne přičíst. (Honza si spletl odčítání a sčítání).

Nejvíc nesouhlasím s Honzou. Je to moc složité. Zbytečně.

Někteří respondenti sice odhalili pravděpodobnou úvahu stojící za Honzovým postupem, ale chybu v ní se nesnažili (nebo nebyli schopni) objasnit. V důsledku toho byly jimi poskytnuté rady př́liš̌ obecné:

S17 4) Honza podle mne zaokrouhlil obě dvě čísla a ty vynásobil dvěma.

Potom asi přičetl sečtená čísla, která chyběla do 40 na obou stranách (pouze domněnka).

5) Viz 4) + procvičit sčítání a odčítání

EvA

Také reakce na Evinu bublinu vykazovaly vysokou hustotu kódů souvisejících s didaktickými znalostmi obsahu.

Někteří respondenti dokázali Evin postup obhájit:

S3 Eva - Úvaha by byla bývala správná, kdyby Eva nezapomněla, že $3+3$ jsou z řádu desítek, nikoliv jednotek. Pak by tedy výslednou šestku přičetla pouze $\mathrm{k}$ jedničce z čísla 17 . Dostala by výsledek 77 .

Jiní se $\mathrm{v}$ něm nedokázali orientovat, což někdy vedlo $\mathrm{k}$ př́liš obecným určením příčin chyb či k nucení dítěte do jiného postupu:

S13 2) Eva.

4) Eva - neumí rozeznat desítky od jednotek.

S5 2) Rozhodně nesouhlasím s Evou.

3) Eva - nemohu sčítat čísla $3+3$, protože 3 je na místě desítek, tudíž je to číslo 30 .

S18 4) Eva: 3 a 3 je $6 \rightarrow$ neuvědomila si, že 3 vyjadřují počet desítek, tudíž musí počítat 30 a 30 je 60 . 


\section{TERKA}

Přestože postup Terky je z nabízených variant asi nejvíce problematický a mohl by indikovat hluboké neporozumění, mezi respondenty vyvolal nejmenší „vášně“.

Obvykle se spokojili s konstatováním, že Terka čísla místo sečtení pouze dala za sebe, ale nepřikládali tomu žádný větší význam:

S13 4) Terka - sečetla desítky zvlášt a jednotky zvlášt a myslela si, že se to píše vedle sebe.

5) Terka - 30 a 30 je správně, 17 také, ale 60 a 17 měla sečíst a ne je napsat vedle sebe.

Objevili se však i respondenti, kteří Terku uvedli jako toho, s kým rozhodně nesouhlasí:

S4 2) Terka

5) Terko, neplet si „přidat“ a „sčítat“. V příkladu musíme sečíst 60 a 17 , ne pridat.

\section{PEPA}

Do prázdné Pepovy bubliny respondenti zpravidla navrhovali různé správné alternativní postupy výpočtu součtu $38+39$, např. rozdělení obou sčítanců na jednotky a desítky, rozdělení druhého sčítance na desítky a jednotky a jejich postupné přičítání k prvnímu sčítanci, písemné sčítání, vyrovnání, využití blízkosti sčítanců a dvojnásobku menšího z nich, opravený Honzův postup:

S5 6) Nejprve sečtu řády $10,30+30=60$, poté sečtu řády jednotek, $8+9=17$. Poté tyto čísla sečtu, $60+17$ a dostanu číslo 77 .

S10 6) $\quad 2 \cdot 30=60, \mathrm{k}$ tomu 9 je 69 a pak ještě $8 \Rightarrow 77$

S11 6) $38+30=68,68+9=77$

S26 6) Z čísla 38 si jedničku půjčím a přidám jí k číslu $39 \Rightarrow 40+37=77$. Lépe se to počítá, protože tam není přechod přes desítku.

S3 6) 38 a do 40 zbývají 2, které si půjčím z 39. Takže mi zbyde $40+37=77$.

S4 6) $\quad(38 \cdot 2)+1=77$

S18 6) Dvakrát 40 a odečteme 3.

Respondenti, kteří do bubliny navrhli nesprávný postup, nabízeli různé miskoncepce související s rolí číslic a řádů v desítkové soustavě:

S23 6) $\quad(3+3)=6$

$(8+9)=17$

$38+39=617$

S16 6) 38

$\frac{39}{67}$

Žák může zapomenout připočíst jedničku ve druhém kroku, kdy $8+7=17,7$ píšu, 1 si pamatuju $\rightarrow$ zapomene na ni, výsledek mu vyjde o 10 menší

Některé miskoncepce se na první pohled podobaly postupům Evy nebo Terky:

S28 6) $\quad 3$ a 8 je 11,3 a 9 je 12 , pak sečtu 11 a 12 a dostanu výsledek 23

S27 6) $\quad 3839 \rightarrow$ složím nové číslo 


\subsubsection{Concept Cartoon na tÉma Zlomky (oBR. 5)}

Tento Concept Cartoon byl respondentům předložen během druhé fáze výzkumu. Je nově vytvořený, inspirovaný jednou z méně úspěšných maturitních úloh. ${ }^{9}$ Podobné úlohy je možné nalézt i v přijímacích zkouškách na víceletá gymnázia (srov. Scio, 2008: s. 31, př. 16).

Z originální sady Concept Cartoons bylo použito pouze pozadí obrázku s dětmi a prázdnými bublinami (Dabell, Keogh \& Naylor, 2008: č. 1.2).

Při tvorbě jsme nově použili takovou kombinaci typů textů v bublinách, která se v originální sadě Concept Cartoons nevyskytuje: tři bubliny obsahují postup řešení a výsledek (chybný), čtvrtá bublina obsahuje jen výsledek (jediný správný) a odkaz na neznámý obrázek, který prý dítěti pomohl při řešení. Obsahy bublin byly

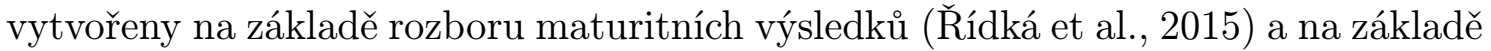
mylných představ žáků uvedených v publikaci Tiché a Macháčkové (2006). Bublina vlevo nahoře obsahuje nejčastěji se vyskytující mylný názor.

Na rozdíl od úlohy z předchozího obrázku bylo pro respondenty obtížné tuto úlohu správně vyřešit, odpovědi na otázku 3 tak byly dvojího typu: souhlas s Pavlou nebo souhlas s Tondou. ${ }^{10}$

\section{PAVla Vs. TONDA}

Respondenti, kteří souhlasili s Pavlou, často rozhodně nesouhlasili s Tondou. Někteří z nich zároveň přiznali, že je to z toho důvodu, že Tondovi vůbec nerozumí, že nechápou, jakým postupem mohl k číslu 6400 dojít:

S12 2) Nesouhlasím s Radkem a Tondou.

3)=4)=5) Tondův názor není správný. Jeho uvažování jsem zcela nepochopila.

Cást respondentů uváděla opravdu zvláštní vysvětlení toho, jak Tonda mohl dojít ke svému výsledku:

S15 4)=5) Tonda počítal $80 \cdot 80$.

S1 Tonda - tento názor je nejvíce chybný $\rightarrow$ nejprve odečetl čtvrtinu (2000) a poté přičetl z každé čtvrtiny 100

S21 4) Tonda - zřejmě si dělal „koláč“ a do počtů započítal i nulu $\rightarrow$ tedy výsledek mu vyšel $8000-1600=6400$

Respondent S21 doplnil svou úvahu obrázkem (obr. 6).

Obr. 6: Ukázka z pracovního listu (S21)

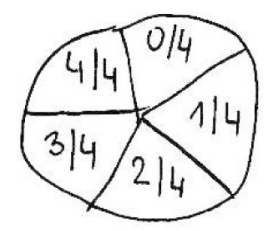

\footnotetext{
${ }^{9}$ Text úlohy: „Na koncert přišlo 800 osob, tedy o čtvrtinu osob více, než organizátoři očekávali. Vypočtěte, kolik osob organizátoři očekávali." (Centrum pro zjištování výsledků vzdělávání, 2015:

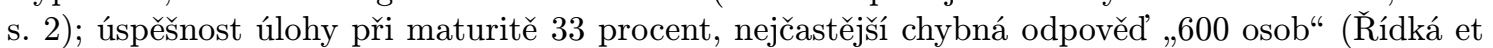
al., 2015).

${ }^{10}$ Naši respondenti byli o něco úspěšnější než maturanti, s Tondou jich souhlasilo 41 procent, zbylých 59 procent souhlasilo s Pavlou.
} 
Objevily se i popisy velice pravděpodobných způsobů, jak by Tonda mohl postupovat, avšak tyto postupy jejich autoři zároveň odmítli jako nesprávné:

S9 2) Tonda

4) Tonda - nejspíš si namaloval obrázek, kde měl čtyři čtvrtiny a tu jednu ještě přičetl, tudíž částku 8000 dělil 5 .

5) Tonda - namaluj si obrázek a ten počet 8000 rozdělíš do kolika dílů, když chceš zjistit $1 / 4$ ?

Respondenti, kteř́i s Tondou souhlasili, podpořili svůj souhlas různě. Někteří nabídli obrázek (viz obr. 7), jiní si sami vyřešili úlohu bez obrázku a porovnali svůj výsledek s Tondovým.

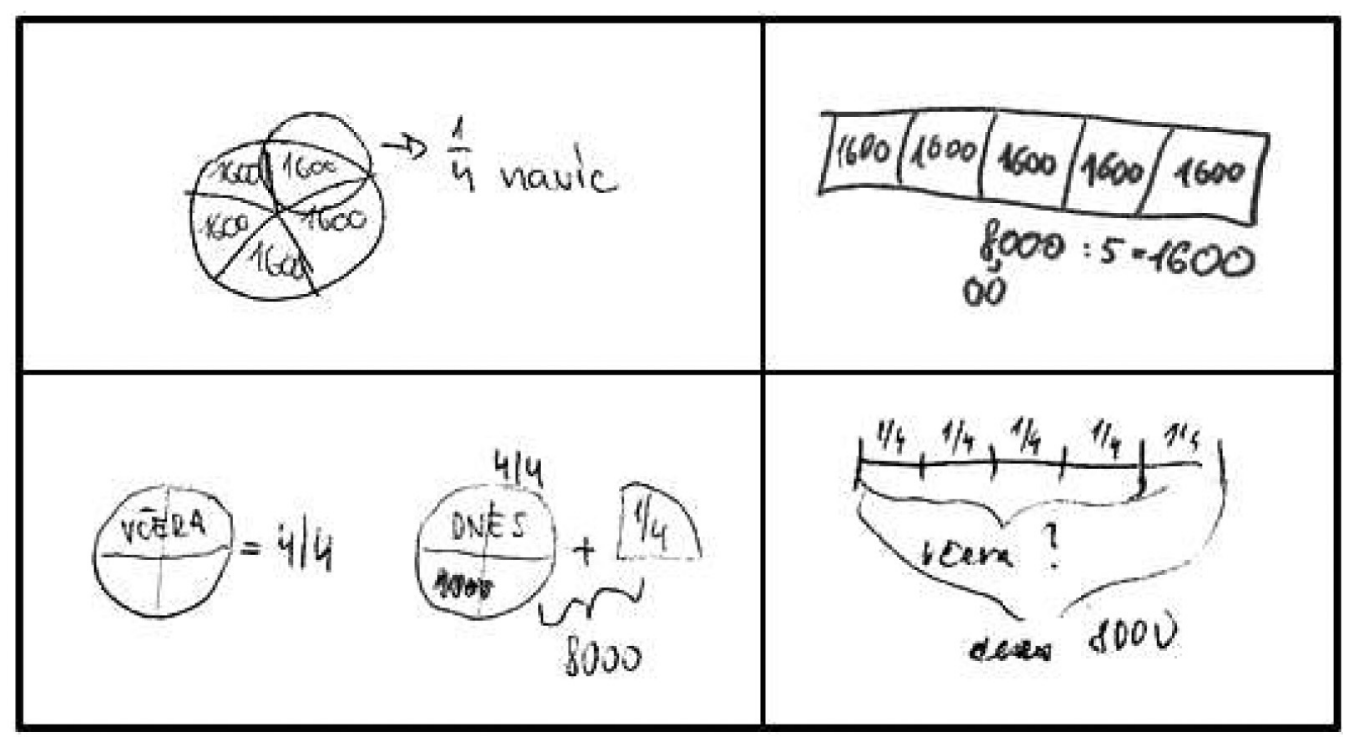

Obr. 7: Ukázky ze čtyř různých pracovních listů, na kterých respondenti souhlasili s Tondou (S24, S4, S22 a S2)

Respondenti souhlasící s Tondou pak zpravidla uměli nalézt chyby v postupech ostatních dětí a zdůvodnit, proč k nim došlo, případně jak je možné chyby opravit: S30 4) Pavla si neuvědomila, že se ta čtvrtina počítá z předchozího celku. Že dnes je diváků včerejší celek + jeho čtvrtina $=8000$

S31 4) Karel - vycházel z čísla 8 000, tedy z dnešního počtu diváků, ne ze včerejšího

$$
\text { Pavla - totéž jako Karel }
$$

S4 4) Pavla - Přičítala čtvrtinu z dnešního místo ze včerejšího.

Radek - Počítal, že dnes je čtvrtina ze včera, ne o čtvrtinu více.

5) Pavla, Karel - Počítáme o čtvrtinu více než včera, takže si musíme spočítat $1 / 4$ ze včerejška, pomohl by Tondův obrázek, to by chybu napravilo. ${ }^{11}$

Radek - Přečti si pozorně zadání: čtvrtina z něčeho $\neq$ o čtvrtinu více

Mezi respondenty byli i takoví, kteří úlohu vůbec neřešili. Správnost Tondova výsledku ověřili zkouškou a u ostatních postupů uvedli důvody, proč si myslí, že jsou chybné:

\footnotetext{
${ }^{11}$ Tondův obrázek od respondenta $\mathrm{S} 4$ je na obr. 7 vpravo nahoře
} 
Pavla - čtvrtina ze včerejšśho počtu, ne dnešního

Radek - špatně, když včera bylo nějaké množství a dnes o $1 / 4$ více, tak včera nemohlo být více lidí než dnes (větší číslo - 32000 hloupost)

S6 3) Pavla - kdyby včera přišlo 6000 diváků, jedna čtvrtina z nich by byla 1500 . Což nám nedá 8000 , ale pouze 7500 .

Karel - kdyby přišlo 8000 diváků včera, byla by jedna čtvrtina 2000 a ty bychom dnes přičetli. 8000 diváků přišlo ale až dnes.

Radek - kdyby byla pravda to, co ř́kal, v zadání by bylo psáno:

Počet diváků: 8000 , to je čtvrtina.

IVA

Obsah Iviny bubliny závisel na výsledku, který respondent považoval za správný. Respondenti, kteří považovali za správný Tondův výsledek, obvykle nabízeli „nápovědu" $\mathrm{k}$ Tondovu výsledku:

S10 6) $\quad 8000$ je $5 / 4$

S22 6) Myslím, že včera bylo o 1600 diváků méně.

S4 6) Je to 6400 , protože podle obrázku je to $4 / 5$ z 8000.

Respondenti, kteří považovali za správný Pavlin výsledek, obvykle nabízeli obrázek ilustrující její postup - koláč rozdělený na čtvrtiny (S16, S18) nebo „nápovědu“ o 8000 jako 4/4 (S12). Některým ani pokus o použití alternativního postupu nepomohl k odhalení vlastní miskoncepce:

S28 6) $\quad x$ diváků ... včera

$$
\begin{aligned}
& \frac{x+1 / 4 d \ldots 8000}{8000: 4=2000} \\
& 2000 \cdot 3=6000
\end{aligned}
$$

V odpovědích se objevily i nerealistické mylné představy:

S29 6) Čtvrtina z 8000 je 6000 , takže včera přišlo jen 2000 diváků.

S11 6) Včera přišlo 4000 lidí. Protože $1 / 4$ je 4000.

Na rozdíl od prvního obrázku Concept Cartoon (oddíl 5.2.1) se mezi návrhy na obsah prázdné Iviny bubliny vůbec nevyskytovaly alternativní postupy řešení.

\section{Diskuse}

Výsledky našeho výzkumného šetření jsou v souladu s poznatky obdobných šetření zabývajících se didaktickými znalostmi obsahu. Podobně jako ve studiích (Krauss, Baumert \& Blum, 2008; Kleickmann et al., 2013) jsme ukázali, že neformální základy didaktických znalostí obsahu mohou někteří budoucí učitelé úspěšně získávat z vlastních zkušeností v roli žáka/studenta na základní škole, střední škole a během nedidaktických univerzitních kurzů, tedy již před univerzitními kurzy didaktiky matematiky a před vlastní pedagogickou praxí.

Někteří naši respondenti prokázali dobré znalosti učebních úloh (různých způsobů jejich řešení) a žákových miskoncepcí. Zároveň však výzkum odhalil i respondenty, kteří nejsou schopni rozlišovat mezi identifikací chyby, prř́činou chyby a nápravou chyby a kteří mají o možném uvažování žáků nerealistické mylné představy. Tyto skutečnosti odpovídají výsledkům podobných výzkumů zaměřených na didak- 
tické znalosti obsahu u budoucích učitelů 1. stupně (např. Turnuklu \& Yesildere, 2007).

Zjištění našeho šetření odkazují na didaktické znalosti obsahu vztahující se ke všem číselným oborům v rozsahu odpovídajícím 1. stupni ZŠ (k přirozeným číslům, k operacím s přirozenými čísly, $\mathrm{k}$ desetinným číslům, k operacím s desetinnými čísly, k celým číslům, k operacím s celými čísly a ke zlomkům). V tomto rysu se šetření podobá např́klad studiím prováděným v rámci projektu COACTIV (přehled studií viz Krauss, Baumert \& Blum, 2008), který ale sledoval jinou skupinu respondentů - učitele matematiky na 2. stupni ZS̆ a na nižších stupních víceletých gymnázií a jejich žáky. Takový přístup nebývá běžný, většina doposud provedených výzkumů didaktických znalostí obsahu se soustředila pouze na jedno dílčí matematické téma (např. násobení zlomků; podrobněji viz přehled výzkumu v Depaepe et al., 2013).

Podobně jako např. ve studiích (Ball, Lubienski \& Mewborn, 2001; Depaepe et al., 2015) se v naší studii potvrdil úzký vztah mezi znalostmi obsahu a didaktickými znalostmi obsahu, nebot u úlohy s nižšími nároky na znalosti obsahu jsme zaznamenali více typů pozitivních projevů didaktické znalosti obsahu (nabídky různých správných alternativních postupů, snaha hledat v chybných postupech správné kroky a na těch postavit rady dětem), kdežto u úlohy s vyššími nároky na znalosti obsahu bylo odhaleno mnohem více typů projevů nedostatečné didaktické znalosti obsahu (nabídky alternativních postupů v podobě nerealistických mylných představ, vysvětlení neznámých postupů vybudovaná na základě nerealistických mylných představ nebo představ zcela nesouvisejících se zadáním úlohy).

Jako výzkumný nástroj jsme použili prostředí obrázků Concept Cartoons. Ukázalo se, že obrázky opatřené sadou doprovodných otázek mohou být vhodným nástrojem pro zkoumání didaktických znalostí obsahu, hlavně v oblastech souvisejících se znalostí učebních úloh a se znalostí žákových poznávacích procesů (srov. Kleickmann et al., 2013). V souladu se studiemi (Keogh \& Naylor, 1999) a (Naylor, Keogh \& Downing, 2007) se také potvrdila schopnost obrázků Concept Cartoons podněcovat řešitele obrázku $\mathrm{k}$ přednesení vlastního názoru na texty $\mathrm{v}$ bublinách a k odpovědím na otázky, i když na rozdíl od původních studií jsme Concept Cartoons použili v jiných kontextech: v matematice a v písemné podobě.

Využívání obrázkových prostředí k výzkumu didaktických znalostí obsahu nebývá běžné, často se v souvislosti s nimi objevují otázky, zdali obrázek nepůsobí spíše rušivě a neodvádí pozornost, zda pro zkoumání znalostí není lepší používat pouze písemné přepisy rozhovorů dětí (tj. soupisy různých alternativ podobně jako v ukázkách v oddíle 1.3). V této souvislosti jsou zajímavá zjištění nedávno realizovaných výzkumných šetření, která se zabývala reakcemi budoucích učitelů na různé formáty reprezentující výukové situace (Herbst \& Kosko, 2013; Herbst, Aaron \& Erickson, 2013; Friesen \& Kuntze, 2016). Během těchto šetření byly učitelům předkládány ke komentování situace z výuky matematiky v různých formátech: videozáznamy, inscenované videozáznamy, obrázkové komiksy (sady na sebe navazujících obrázků s názory žáků a někdy i učitelů) a texty (přepisy dialogů). Analýza dat neodhalila žádné podstatné rozdíly mezi jednotlivými formáty z hlediska kvality reakcí respondentů (tj. z pohledu kódování), nebyl odhalen ani žádný vliv zvoleného formátu na obtížnost úkolu.

Obrázky Concept Cartoons jsme použili pro zjištoování reakcí budoucích učitelů na různé alternativní názory žáků, v jistém smyslu jsme tak vlastně u respondentů zkoumali neformální základy jejich schopnosti všímat si (Stehlíková, 2010), a to konkrétně její kategorii související s komentováním žákových promluv (kategorie pupil commentary; Vondrová \& Žalská, 2015). 
Studie (Depaepe et al., 2015) vytýká některým předchozím studiím zabývajícím se didaktickými znalostmi obsahu, že nezkoumají didaktické znalosti obsahu nezávisle na znalostech obsahu, tj. že respondenti nejprve řeší nějakou úlohu, aby prokázali své znalosti obsahu, a potom se v kontextu té samé úlohy vyjadřují k záležitostem souvisejícím s didaktickými znalostmi obsahu. Dle názoru autorů studie tato závislost negativně ovlivňuje data související s didaktickými znalostmi obsahu. Při použití obrázků Concept Cartoons k žádné podobné závislosti nedochází, nebot vyřešení úlohy není požadováno, a tak respondenti mohou prokázat své didaktické znalosti obsahu i v př́padě, že úlohu neumí vyřešit - například tak, že správně provedou zkoušku výsledků nabízených dětmi, nebo že nezávisle na (jim neznámém) řešení úlohy dokážou dětem vysvětlit, proč některé postupy nemohou být správné.

Významnou komponentou obrázků Concept Cartoons je prázdná bublina, která umožňuje získat vhled do znalostí alternativních postupů a možných žákových miskoncepcí. Spektrum odpovědí našich respondentů bylo skutečně pestré, ale při zpětném pohledu na získaná data je vidět, že odpovědi byly zbytečně limitovány požadavkem uvést (pouze) jednu alternativu, která by mohla v prázdné bublině být (správnou, nebo chybnou). Potenciál této komponenty Concept Cartoons tak nebyl zdaleka vyčerpán. Pro další šetření by bylo vhodné nechat se inspirovat testovými úlohami ze studie (Kleickmann et al., 2013) a otázku související s prázdnou bublinou rozdělit na dvě části a přeformulovat tak, aby respondenty vyzývala k uvedení co největšího množství možných alternativních postupů a co největšího množství možných žákových miskoncepcí. Takový přístup by pak mohl umožnit srovnání získaných dat např. s výzkumem (Tirosh, 2000), v rámci kterého byly odhaleny obtíže, jež mají budoucí učitelé s předvídáním chyb svých žáků. Výzkum zabývající se didaktickými znalostmi obsahu souvisejícími s dělením zlomků mj. ukázal, že ti budoucí učitelé, kteř́i jsou schopni chyby žáků předvídat, většinou předvídají jen procedurální chyby, tedy chyby $\mathrm{v}$ algoritmech nebo chyby na algoritmech založené. Naše data bohužel závěry tohoto typu neumožňují, protože respondenti do prázdných bublin nabízeli spíše alternativní správné postupy nebo rady, a tak je dat souvisejících s předvídáním chyb žáků velmi málo.

Poněkud problematickými se po přípravné studii jevily otázky zjištující, s kterým dítětem na obrázku respondent nejvíce (ne)souhlasí. Otázky byly původně do sady zařazeny s úmyslem zkoumat spontánní reakce na názory v bublinách, nebot byly předkládány jako první v pořadí a nevyžadovaly po respondentech žádné zdůvodnění odpovědi. Při pročítání vyplněných pracovních listů však nebylo možné zkontrolovat, zda odpovědi na ně byly skutečně vypracovávány jako první, a tak ve vlastní studii otázky zůstaly jen jako zdroj dat obohacujících odpovědi na otázky, jež zdo̊vodnění vyžadovaly. Po zkušenostech z vlastního šetření a s jistým časovým odstupem lze konstatovat, že zařazení těchto otázek bylo pro šetření přínosem, ale že je třeba se také vrátit $\mathrm{k}$ původnímu úmyslu zkoumat spontánní reakce respondentů na názory v bublinách. Ve studiích (Krauss \& Brunner, 2008; Pankow et al., 2016) bylo pro obdobné účely využito počítačové prostředí. V první studii se respondentům postupně na monitoru objevovaly matematické úlohy s žákovou odpovědí a úkolem respondentů bylo se co nejrychleji rozhodnout, zda žák odpověděl správně, nebo špatně. V druhé studii bylo úkolem respondentů předvídat u úloh zobrazovaných na monitoru typické žákovské chyby. Taková počítačová uspořádání umožňovala zaznamenávat i časy, které respondenti potřebovali na svá rozhodnutí, a dávat je do souvislosti s obtížností úloh, se správností odpovědí jednotlivých respondentů apod. Jedním z dalších možných rozššření našeho výzkumného šetření by tak mohlo být rozdělení sběru dat na dvě oddělené etapy: v první etapě předložit responden- 
tům Concept Cartoons pouze s otázkami na to, s kterým dítětem respondent nejvíce souhlasí a s kterým nejvíce nesouhlasí, s velmi krátkým časovým limitem na odpovědi a možným využitím počítače; v druhé etapě pak předložit Concept Cartoons ve formě popisované v naší studii. Podobný etapový přístup byl zvolen ve výzkumném šetření (Depaepe et al., 2015), kde byly respondentům v oddělených etapách předkládány dvojice souvisejících úloh, vždy v jedné etapě úloha testující znalosti obsahu a v té druhé úloha testující didaktické znalosti obsahu.

\section{OMEZENí VÝZKUMU}

Předložený výzkum má několik omezení:

- zkoumaný vzorek je relativně malý a výsledky výzkumu platí právě jen pro něj, není možné je zobecňovat; ${ }^{12}$

- zkoumány jsou jen některé komponenty didaktických znalostí obsahu, zcela opomenuty tak zůstávají znalosti související s cíli vyučování, s kurikulem a s výukovými strategiemi, znalosti reprezentací jsou zkoumány pouze částečně;

- samotné Concept Cartoons jsou určitým omezením, nebot poskytují pouze úzký statický pohled na didaktické situace, ke kterým může ve třídě dojít;

- výzkum je zaměřen kognitivně a nikterak nezohledňuje afektivní aspekty (osobnost učitele, jeho vztah k matematice a matematickému vzdělávání apod.);

- vzhledem $\mathrm{k}$ písemné podobě pracovních listů mohla být některá tvrzení respondentů při analýze dat nesprávně interpretována a není možné jednoznačně odlišit př́pady, kdy respondent neuměl reagovat na nějakou zobrazenou situaci, od př́padů, kdy se nesnažil nebo úmyslně nechtěl reagovat.

\section{ZÁVĚR}

Přes výše uvedená omezení považujeme předložený výzkum za relevantní sondu do didaktických znalostí obsahu budoucích učitelů. Získané výsledky poskytují přehled o jednotlivých respondentech, o jejich reakcích na hypotetické názory žáků v různých matematicky zaměřených situacích.

Předložená studie je součástí dlouhodobého projektu, výzkum se stejnými respondenty pokračuje. Budeme sledovat, jak se na datech získaných prostřednictvím Concept Cartoons projeví vliv absolvovaného kurzu didaktiky, a konfrontovat získané poznatky s videozáznamy pořízenými během studentských vystoupení při průběžných pedagogických praxích.

\section{PODĚKOVÁNí}

Tato studie byla realizována s finanční podporou projektu GAČR 14-01417S Zkvalitňování znalostí matematického obsahu u budoucích učitelů 1. stupně prostřednictvím badatelsky orientované výuky.

\footnotetext{
${ }^{12}$ Zároveň je však třeba připomenout, že výzkumu se zúčastnili všichni studenti z daného studijního ročníku - v tomto smyslu jsou data reprezentativní.
} 


\section{LITERATURA}

Ball, D. L., Lubienski, S. T. \& Mewborn, D. S. (2001). Research on teaching mathematics: The unsolved problem of teachers' mathematical knowledge. In V. Richardson (Ed.), Handbook of research on teaching (433-456). New York: Macmillan.

Bana, J., Farrell, B. \& McIntosh, A. (1995). Error patterns in mental computation in years 3-9. In B. Atweh \& S. Flavel (Eds.), Galtha: Conference Proceedings of the 18th Annual Conference of MERGA (51-56). Darwin: MERGA.

Berg, E. van den. (2013). Didaktická znalost obsahu v laboratorní výuce: Od práce s př́stroji k práci s myšlenkami. Scientia in educatione, 4(2), 74-92.

Berg, E. van den. (2014). Learning to investigate with concept cartoons. In V. Koudelková \& L. Dvořák (Eds.), Dílny Heuréky 2013 (7-13). Praha: Nakladatelství P3K.

Centrum pro zjištování výsledků vzdělávání (2015). Matematika - Didaktický test MAMZD15C0T04. Dostupné

z http://www.novamaturita.cz/zadani-pisemnych-zkousek-podzim-2015-1404037935.html

Dabell, J. (2008). Using Concept Cartoons. Mathematics Teaching, 209, 34-36.

Dabell, J., Keogh, B. \& Naylor, S. (2008). Concept Cartoons in Mathematics Education. Sandbach: Millgate House Education.

Department for Education (2010). Teaching children to calculate mentally. STEM learning resources. Dostupné z http://stem.org.uk

Depaepe, F., Torbeyns, J., Vermeersch, N., Janssens, D., Janssen, R., Kelchtermans, G., Verschaffel, L. \& Van Dooren, W. (2015). Teachers' content and pedagogical content knowledge on rational numbers: a comparison of prospective elementary and lower secondary school teachers. Teaching and Teacher Education, 47, 82-92.

Depaepe, F., Verschaffel, L. \& Kelchtermans, G. (2013). Pedagogical content knowledge: A systematic review of the way in which the concept has pervaded mathematics educational research. Teaching and Teacher Education, 34, 12-25.

Friesen, M. \& Kuntze, S. (2016, srpen). Teacher students analyse texts, comics and video-based classroom vignettes regarding the use of representations - Does format matter? Příspěvek přednesený na mezinárodní konferenci PME, Szeged, Mad’arsko.

Fronek, J. (1999). Anglicko-český, česko-anglický slovník. Praha: LEDA.

Gavora, P. (2010). Úvod do pedagogického výzkumu. Brno: Paido.

Grossman, P. L. (1990). The making of a teacher: Teacher knowledge and teacher education. New York: Teachers College Press.

Hansen, A. (Ed.) (2011). Children' errors in mathematics. Understanding common misconceptions in primary schools. London: SAGE.

Hejnová, E. (2013, duben). Konceptuální úlohy pro aktivní učení na základní škole. Příspěvek prezentovaný na konferenci Moderní trendy v přípravě učitelů fyziky 6 , Kašperské Hory.

Hejný, M. \& Stehlíková, N. (1999). Zkoumání číselných představ dítěte a žáka. Pokroky matematiky, fyziky a astronomie, 44(2), 148-167.

Herbst, P., Aaron, W. \& Erickson, A. (2013). How preservice teachers respond to representations of practice: A comparison of animations and video. Příspěvek přednesený na konferenci AERA, San Francisco, USA. 
Herbst, P. \& Kosko, K. W. (2013). Using representations of practice to elicit mathematics teachers' tacit knowledge of practice: a comparison of responses to animations and videos. Journal of Mathematics Teacher Education, 17(6), 515-537.

Hošpesová, A. (2003). Procesuální a pojmové myšlení ve vytváření aditivní poznatkové struktury. [Habilitační práce]. Olomouc: Univerzita Palackého, Pedagogická fakulta.

Janík, T. (2004). Význam Shulmanovy teorie pedagogických znalostí pro oborové didaktiky a pro vzdělávání učitelů. Pedagogika, 54(3), 243-250.

Janík, T. et al. (2007). Pedagogical content knowledge nebo didaktická znalost obsahu? Brno: Paido.

Janík, T. (2009). Didaktické znalosti obsahu a jejich význam pro oborové didaktiky, tvorbu kurikula a učitelské vzdělávání. Brno: Paido.

Keogh, B. \& Naylor, S. (1993). Learning in science: another way in. Primary Science Review, 26, 22-23.

Keogh, B. \& Naylor, S. (1999). Concept cartoons, teaching and learning in science: an evaluation. International Journal of Science Education, 21(4), 431-446.

Keogh, B., Naylor, S., Boo, M. de \& Feasey, R. (1999). The use of concept cartoons as an auditing tool in initial teacher training. Př́spěvek prezentovaný na konferenci ESERA, Kiel, Německo.

Kittler, J. (1994). Matematika pro 1. ročník základni školy, učebnice. Praha: Matematický ústav AV ČR.

Kleickmann, T., Richter, D., Kunter, M., Elsner, J., Besser, M., Krauss, S. \& Baumert, J. (2013). Teachers' content and pedagogical content knowledge: the role of structural differences in teacher education. Journal of Teacher Education, 64, 90-106.

Kořínek, M. (1965). K otázce spojů v nižších ročnících ZDŠ. Pedagogika, 15(6), 691-705.

Krauss, S., Baumert, J. \& Blum, W. (2008). Secondary mathematics teachers' pedagogical content knowledge and content knowledge: validation of the COACTIV constructs. ZDM Mathematics Education, 40, 8873-8 892.

Krauss, S. \& Brunner, M. (2008). Professionelles Reagieren auf Schülerantworten: Ein Reaktionszeittest für Mathematiklehrkräfte. In E. Vásárhelyi (Ed.), Beiträge zum Mathematikunterricht 2008. Vorträge auf der 42. Tagung für Didaktik der Mathematik vom 13. 3. bis 18. 3. 2007 in Budapest. (400-403). Münster: WTM-Verlag.

Kuřina, F. (2011). Třri pokusy řešit neřešitelné. Pedagogika, 61(1), 5-12.

Kuřina, F. (2012). Didaktické znalosti obsahu a matematické vzdělávání učitelů. Pedagogická orientace, 22(2), 162-180.

Minárechová, M. (2014). Využitie metódy concept cartoons(Cpri modifikácii žiackych predstáv o prírodných javoch. PEDAGOGIKA.SK, 5(2), 137-159.

Naylor, S. \& Keogh, B. (2007). Active assessment: thinking, learning and assessment in science. School Science Review, 88(325), 73-79.

Naylor, S. \& Keogh, B. (2010). Concept Cartoons in Science Education, $2^{\text {nd }}$ Edition. Sandbach: Millgate House Education.

Naylor, S. \& Keogh, B. (2013). Concept Cartoons: What have we learnt? Journal of Turkish Science Education, 10(1), 3-11.

Naylor, S., Keogh, B. \& Downing, B. (2007). Argumentation and primary science.

Research in Science Education, 37, 17-39. 
Pankow, L., Kaiser, G., Busse, A., König, J., Blömeke, S., Hoth, J. \& Döhrmann, M. (2016). Early career teachers' ability to focus on typical students errors in relation to the complexity of mathematical topic. ZDM, 48(1-2), 55-67.

Rowland, T., Huckstep, P. \& Thwaites, A. (2005). Elementary teachers' mathematics subject knowledge: the knowledge quartet and the case of Naomi. Journal of Mathematics Teacher Education, 8, 255-281.

Rowland, T., Thwaites, A. \& Jared, L. (2016). Analysing secondary mathematics teaching with the knowledge quartet. Př́spěvek přednesený na mezinárodní konferenci ICME-13, Hamburg, Německo.

Rowland, T., Turner, F., Thwaites, A. \& Huckstep, P. (2009). Developing primary mathematics teaching. Reflecting on practice with the knowledge quartet. London: SAGE.

Rowland, T., Turner, F. \& Thwaites, A. (2014). Research into teacher knowledge: a stimulus for development in mathematics teacher education practice. ZDM Mathematics Education, 46, 317-328.

Ryan, J. \& Williams, J. (2011). Children's mathematics 4-15. Learning from errors and misconceptions. Berkshire: Open University Press.

Rídká, E. et al. (2015, září). Současný stav maturit z matematiky. Příspěvek na LXIV. Akademickém Fóru Odborné skupiny Organizace výzkumu České fyzikální společnosti JČMF, Praha.

Samková, L. \& Hošpesová, A. (2015). Using Concept Cartoons to investigate future teachers' knowledge. In K. Krainer \& N. Vondrová (Eds.), Proceedings of CERME 9 (3241-3247). Praha: Univerzita Karlova, Pedagogická fakulta.

Samková, L. \& Tichá, M. (2015). Investigating future primary teachers' grasping of situations related to unequal partition word problems. In C. Sabena \& B. Di Paola (Eds.), Quaderni di Ricerca in Didattica (Mathematics), n. 25, Supplemento n. 2. Proceedings CIEAEM 67, Teaching and learning mathematics: resources and obstacles (295-303). Palermo, Italy: G.R.I.M.

Samková, L., Tichá, M. \& Hošpesová, A. (2015). Error patterns in computation in Concept Cartoons. In J. Novotná \& H. Moraová (Eds.), International Symposium Elementary Maths Teaching SEMT '15. Proceedings (390-391). Praha: Univerzita Karlova, Pedagogická fakulta.

Scio (2008). Testy z víceletých gymnázii 2009 - matematika. Brno: Didaktis.

Shulman, L. S. (1986). Those who understand: knowledge growth in teaching.

Educational Researcher, 15(2), 4-14.

Shulman, L.S. (1987). Knowledge and teaching. Foundations of the new reform. Harvard Educational Review, 57(1), 1-22.

Stehlíková, N. (2010). Interpretace některých didakticko-matematických jevů u studentů učitelství a u učitelů matematiky. Pedagogika, 60(3-4), 303-313.

Švaříček, R. \& Šedová, K. (2014). Kvalitativní výzkum v pedagogických vědách. Praha: Portál.

Tichá, M. \& Macháčková, J. (2006). Rozvoj pojmu zlomek ve vyučování matematice. In Podíl učitele matematiky Zگ̆ na tvorbě $\breve{S} V P$ : Studijní materiály k projektu. Praha:

JC̈MF. [CD-ROM]

Tirosh, D. (2000). Enhancing prospective teachers' knowledge of children's conceptions: the case of division of fractions. Journal for Research in Mathematics Education, 31, $5-25$. 
Trnová, E., Janko, T., Trna, J. \& Pešková, K. (2016). Typy vzdělávacích komiksů a analýza jejich edukačního potenciálu pro přírodovědnou výuku. Scientia in educatione, $7(1), 49-64$

Turnuklu, E. B. \& Yesildere, S. (2007). The pedagogical content knowledge in mathematics: pre-service primary mathematics teachers' perspectives in Turkey. Issues in the Undergraduate Mathematics Preparation of School Teachers, 1, 1-13.

Vondrová, N. \& Žalská, J. (2015). Ability to notice mathematics specific phenomena: What exactly do student teachers attend to? Orbis Scholae, 9(2), 77-101.

LIBUŠE SAMKOVÁ, lsamkova@pf.jcu.cz

Jihočeská univerzita v Českých Budějovicích, Pedagogická fakulta

Katedra matematiky

Jeronýmova 10, 37115 České Budějovice, Česká republika 